\title{
Crustal Structure in Central-Eastern Greenland From Receiver Functions
}

Kraft, Helene A.; Thybo, Hans; Vinnik, Lev P.; Oreshin, S.

Published in:

Journal of Geophysical Research: Solid Earth

DOI:

10.1029/2018JB015919

Publication date:

2019

Document version

Publisher's PDF, also known as Version of record

Citation for published version (APA):

Kraft, H. A., Thybo, H., Vinnik, L. P., \& Oreshin, S. (2019). Crustal Structure in Central-Eastern Greenland From Receiver Functions. Journal of Geophysical Research: Solid Earth, 124(2), 1653-1670.

https://doi.org/10.1029/2018JB015919 


\author{
RESEARCH ARTICLE \\ 10.1029/2018JB015919 \\ Key Points: \\ - Crustal structure of interior \\ central-eastern Greenland shows \\ strong variation in Moho depth from \\ 15 to $50 \mathrm{~km}$ \\ - Seismic velocity of the crust is highly \\ variable based on Seismic Receiver \\ Function inversion \\ - Crustal Airy isostasy cannot explain \\ the high topography in eastern \\ Greenland
}

Supporting Information:

- Supporting Information S1

Correspondence to:

H. Thybo,

thybo@geo.uio.no

Citation:

Kraft, H. A., Thybo, H., Vinnik, L. P., \& Oreshin, S. (2019). Crustal structure in Central-Eastern Greenland from receiver functions. Journal of Geophysical Research: Solid Earth, 124, 1653-1670. https://doi.org/10.1029/ 2018JB015919

Received 7 APR 2018

Accepted 21 DEC 2018

Accepted article online 28 DEC 2018

Published online 8 FEB 2019

c)2018. American Geophysical Union. All Rights Reserved.

\section{Crustal Structure in Central-Eastern Greenland From Receiver Functions}

\author{
Helene A. Kraft ${ }^{1}$, Hans Thybo ${ }^{2,3,4}$ D, Lev P. Vinnik ${ }^{5}$ D , and S. Oreshin $^{5}$ \\ ${ }^{1}$ IGN, Geology Section, University of Copenhagen, Copenhagen, Denmark, ${ }^{2}$ Eurasia Institute of Earth Sciences, Istanbul \\ Technical University, Istanbul, Turkey, ${ }^{3}$ Centre for Earth Evolution and Dynamics, University of Oslo, Oslo, Norway, \\ ${ }^{4}$ China University of Geosciences, Wuhan, China, ${ }^{5}$ Institute of Physics of the Earth, Moscow, Russia
}

Abstract The crustal structure in the interior of Greenland is largely unknown because of its remote location below the up to 3.4-km-thick ice sheet. We present a model of the crustal velocity structure in central-eastern Greenland based on simultaneous inversion of $P$ and $S$ receiver functions for data acquired at 23 broadband stations between the coast and the center of the ice sheet. The area is believed to mainly include Precambrian basement and includes a part covered by Tertiary volcanic rocks and some sedimentary basins. Our results show a westward deepening Moho from less than $20 \mathrm{~km}$ at the coast to $50 \mathrm{~km}$ below central Greenland. Crustal $S$ wave velocities are generally $3.75 \mathrm{~km} / \mathrm{s}$ through the whole crust which may be relatively small for Precambrian areas, and $V_{p} / V_{s}$ is generally around 1.73 , although slightly higher in central Greenland. In the coastal area we observe anomalously low velocities at the top of the crust. In the volcanic area south of Scoresbysund Fjord this layer has very high $V_{p} / V_{S}(>2)$, which indicates a high mafic content and the presence of water-filled cracks in the basaltic material. In the north, outside the volcanic area, $V_{p} / V_{s}$ is normal and the low-velocity layer probably is instead related to the presence of sedimentary basins. At stations in the center of our study area we find low $V_{s}$ and high $V_{p} / V_{s}$ in the lower crust. Based on the Moho topography, our results do not support Airy type isostasy as explanation of the high topography in eastern Greenland.

Plain Language Summary Crustal structure in interior Greenland is largely unknown due to its inaccessibility. The origin of the mountains at the rim of Greenland is enigmatic, and cannot be explained by standard plate tectonic processes. We present the first crustal structure profile across the mountains and to the centre of Greenland which is needed for constraining the possible mechanisms that formed the mountains. We conclude that crustal isostasy cannot explain their presence.

\section{Introduction}

Unusually high mountains are present along the whole of the passive margins on both sides of the North Atlantic Ocean with altitudes reaching 2,500 $\mathrm{m}$ in southern Norway and 3,700 $\mathrm{m}$ in central eastern Greenland. Similar high mountain ranges exist at other passive margins in, for example, Brasil, South Africa, and eastern Australia. Whereas plate tectonic theory explains the presence of mountain ranges at plate boundaries, it does not explain the existence of high mountain ranges outside plate boundaries, such as along passive margins. In order to study the origin of such enigmatic mountain ranges, a series of experiments are being conducted in Scandinavia and Greenland, in particular by seismological methods (e.g., England \& Ebbing, 2012; Kvarven et al., 2016; Maupin et al., 2013; Stratford \& Thybo, 2011; Weidle et al., 2010), fission track estimates of uplift rates (e.g., Hendriks \& Redfield, 2005; Japsen et al., 2005; Pedersen et al., 2012), geomorphology (e.g., Japsen et al., 2006, 2009), and other geological methods (e.g., Anell et al., 2010, 2012; Gabrielsen et al., 2010). Most studies have for logistical reasons been carried out in Scandinavia. For an overview we refer to Anell et al. (2009). Three seismological studies were conducted in eastern to central Greenland during 2009-2013: 10 broadband seismometers were deployed along a profile around $73^{\circ} \mathrm{N}$ (Schiffer et al., 2014), an active source seismic profile was acquired around $70^{\circ} \mathrm{N}$ on the ice sheet (Shulgin \& Thybo, 2015), and the data for the present study were acquired between 70 and $72^{\circ} \mathrm{N}$ from the east coast to the center of the ice sheet (Kraft et al., 2018).

The geological and geophysical knowledge of interior Greenland is very limited, because more than $80 \%$ of the area is covered by the up to 3.4-km-thick ice sheet (Figure 1). This leads to challenging conditions for geophysical fieldwork and previous studies were controlled-source experiments conducted offshore on the 


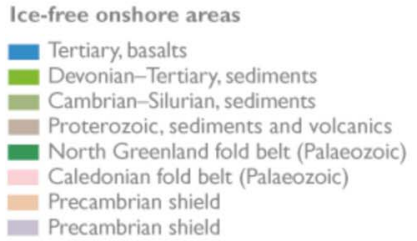

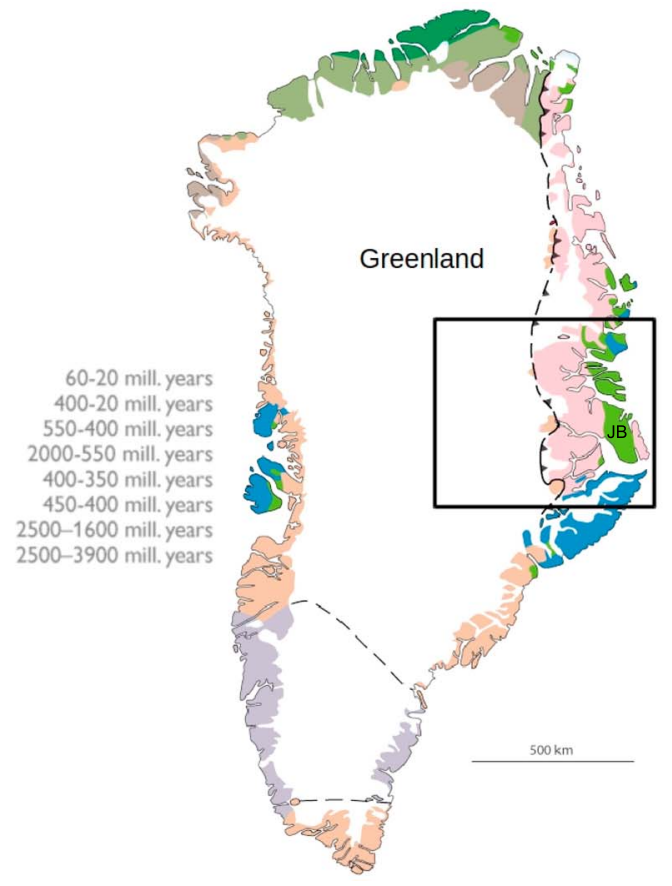

Figure 1. Geological map of Greenland (after Henriksen, 2008). Printed with permission from GEUS (geological survey of Denmark and Greenland). The onshore tertiary basaltic provinces form part of the North Atlantic Igneous Province (NAIB). The Jameson Basin is the largest of the Devonian to Tertiary basins in Greenland-marked JB.

continental margin and at the continent-ocean transition (e.g., Chian \& Louden, 1992; Dahl-Jensen et al., 1998; Døssing et al., 2016; Funck et al., 2017; Holbrook et al., 2001; Hopper et al., 2003; Kvarven et al., 2016; Schlindwein \& Jokat, 1999; Voss et al., 2009; Voss \& Jokat, 2007) and on the ice-free onshore parts (Voss et al., 2009; Hermann \& Jokat, 2016; for an overview, see Artemieva \& Thybo, 2013). The GLATIS project (Dahl-Jensen et al., 2003) was the first seismological study to include the ice-covered interior of continental Greenland. These data were used for receiver function studies (Dahl-Jensen et al., 2003; Kumar et al., 2007), surface wave tomography (Darbyshire et al., 2004), and SKS splitting analysis (Ucisik et al., 2008). These studies were based on data from 16 stations (of which four were located on the ice sheet), covering an area of $2,166,000 \mathrm{~km}^{2}$ with a station spacing of several hundreds of kilometers, and they led to the first seismological knowledge of the structure of the lithosphere of interior Greenland at low resolution. Recently, Darbyshire et al. (2018) interpreted the crustal structure of Greenland by surface wave analysis of new data from the Greenland Ice Sheet Monitoring Network (GLISN) project.

Only very recently the first regional seismological studies in onshore Greenland were carried out. Schiffer et al. (2014) interpret an eastward dipping interface detected by seismic receiver functions as a fossil subduction zone close to the east coast at around $73^{\circ} \mathrm{N}$ based on $P$ receiver functions. Kraft et al. (2018) image the fine structure of the mantle transition zone and interpret it in terms of the thermal structure. Shulgin and Thybo (2015) analyze the first active source seismic profile data acquired on the ice sheet and observe a Moho depth of approximately $50 \mathrm{~km}$ in the center of Greenland to the south of the Summit station and slightly shallower values of around $42 \mathrm{~km}$ in the eastern part of the ice-covered part of our study area around STA12 (Figure 2).

Here we provide the first detailed areal interpretation of crustal structure in an area of approximately 200 by $600 \mathrm{~km}$ size in central-eastern Greenland. We base the interpretation on joint $P$ and $S$ wave receiver function inversion for velocity structure by analyzing data from 23 stations that were deployed on basement rocks near the coast and on the ice cover in the interior parts of Greenland.

\subsection{Geological Setting}

The major part of Greenland is a Precambrian shield including an Archaean block of unknown extent below the ice in the south, and several Proterozoic mobile belts, partly consisting of reworked Archaean terranes 


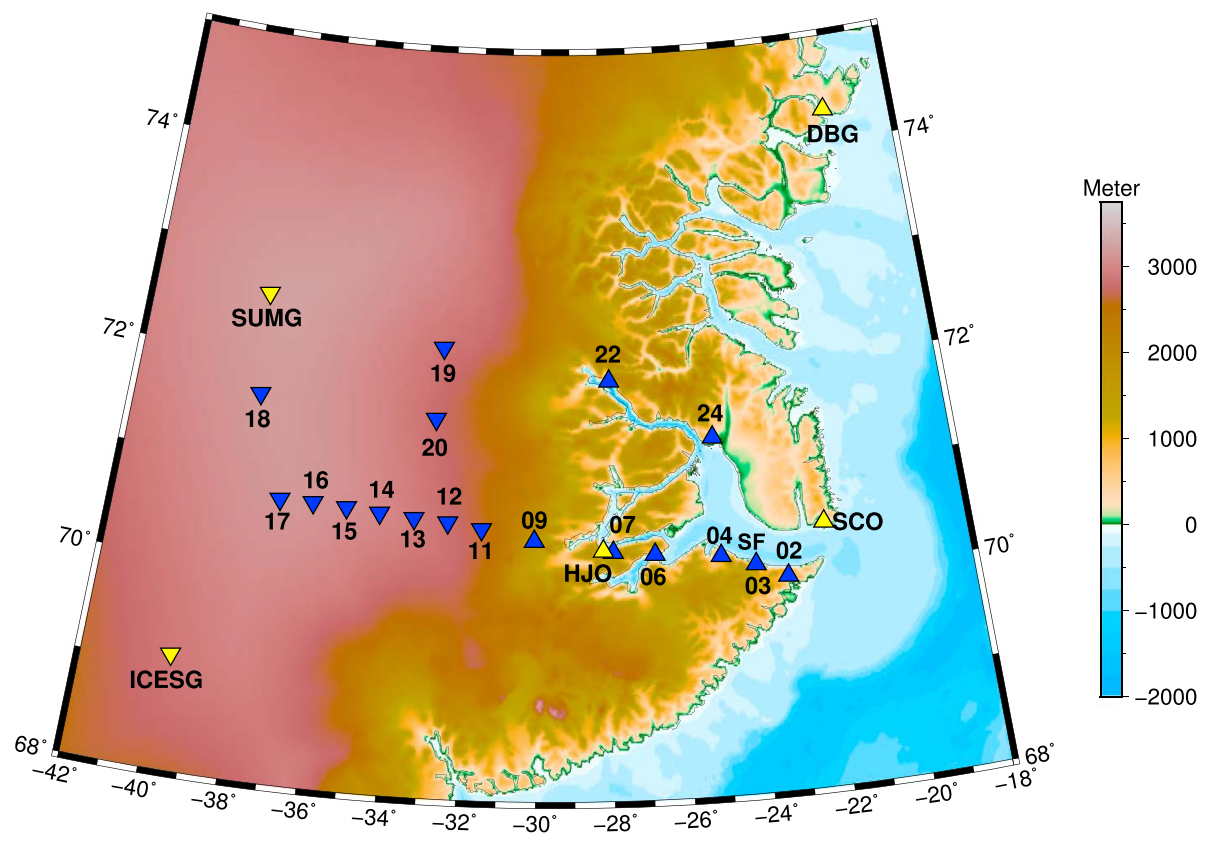

Figure 2. Topography in the study area and locations of the stations used for receiver function calculations. Blue triangles mark the stations of the temporary deployment from 2009 to 2012, and yellow triangles mark the stations from the GLISN and GLATIS projects. Upright triangle means that the station was installed on bedrock, and upside down triangle means station installed on ice. SF marks the Scoresbysund Fjord. Topography data from Amante and Eakins (2012).

(Figure 1). The northern half of the east coast is dominated by the up to 300-km-wide Caledonian fold belt, which originates from the collision between Laurentia and Baltica after the closure of the Iapetus Ocean.

Mountain ranges exist on both sides of the North Atlantic. They include the Caledonian fold belt, an approximately 55-Ma-old volcanic region connected to the North Atlantic Igneous Province (NAIP), large inverted sedimentary basins with Mesozoic sediments at elevations up to 1,000 $\mathrm{m}$, and large areas with Precambrian basement rocks (Figure 1). It is highly debated whether the current topography of up to $3.7 \mathrm{~km}$ on the two sides of the North Atlantic Ocean is a remnant of the Caledonian orogeny (Doré et al., 2002; Pedersen et al., 2012) or caused by more recent uplift during the last $65 \mathrm{Ma}$ (Gabrielsen et al., 2010; Japsen et al., 2014; Japsen \& Chalmers, 2000). However, the former model can only explain the topography in the areas affected by the Caledonian orogeny but not Precambrian areas along most of the coast of Greenland, as well as the Mesozoic inverted basins and the NAIP related volcanic rocks that presumably erupted around sea level. Recent GPS studies have revealed uplift rates of up to $30 \mathrm{~mm} /$ year at one station in eastern Greenland close to the volcanic field (Bevis et al., 2012). Anell et al. (2009) present a review of the current knowledge of uplift in this region.

During the initial rifting and opening of the North Atlantic Ocean, Phanerozoic sedimentary basins formed in North and North-East Greenland, including the Jameson Basin (Figure 1) inside our study area with sediment thicknesses of up to $18 \mathrm{~km}$ below Jurassic sedimentary rocks (Henriksen et al., 2009). Another enigmatic feature of Greenland's geology are the outcrops of basalts on both the east and the west coast. On the west coast these outcrops are believed to be between 4 and $10 \mathrm{~km}$ thick and most of the eruptions took place between 62 and $60 \mathrm{Ma}$, with the youngest material dated to be $55 \mathrm{Ma}$ (Henriksen et al., 2009). The basalts at the east coast are slightly younger ( 56 to $55 \mathrm{Ma}$ ) and also form layers believed to be more than $5 \mathrm{~km}$, possibly up to $10 \mathrm{~km}$ thick (Brooks, 2011; Larsen et al., 2014). These volcanic rocks were emplaced as a part of the North Atlantic Igneous Province (NAIP), which covers a large area of the North Atlantic region and had its main magmatic phase between approximately 60.5 and approximately 54.5 Ma (Jolley \& Bell, 2002; Petrov et al., 2016). Nevertheless, it is difficult to explain the magmatic material at the west coast by the NAIP.

The suggested track of the Iceland hot spot below Greenland (Lawver \& Müller, 1994) may explain the magmatism in West and East Greenland, but this reconstruction shows that the hot spot was located at the west 
coast at approximately $70 \mathrm{Ma}$ and at the east coast at approximately $40 \mathrm{Ma}$. Another more recent reconstruction indicates that the Iceland hot spot remained close to the east coast of Greenland within our study area from approximately 70 to approximately $40 \mathrm{Ma}$ (Torsvik et al., 2015). Hence, the relation between the NAIP and the Iceland hot spot track remains unclear. Henriksen et al. (2009) provide a detailed description of the surface geology of Greenland as an authoritative source of information.

\section{Data and Method}

\subsection{Data Set}

We present the results of receiver function inversion for crustal velocity structure in central-eastern Greenland based on data from 23 broadband stations. The main part of the data has been acquired with 18 Streckeisen STS-2 three-component broadband stations, which were temporarily installed from June 2009 until May 2012 (10 stations on the ice sheet) and June 2011 ( 8 stations on bedrock). The stations covered an area of around $200 \mathrm{~km} \times 600 \mathrm{~km}$ between Scoresbysund Fjord (Figure 2) at the east coast and the center of the ice shield. Thirteen stations formed a profile along $70^{\circ} \mathrm{N}$ with a station spacing of around $35 \mathrm{~km}$, and the remaining 5 stations covered the area further north (Figure 2). The 10 seismometers on the ice were installed in 2-m-deep holes on a wooden plate, insulated, and then covered with snow. All stations were powered from solar panels. Due to the high latitudes and the resulting lack of sunlight during winter all stations ran out of power for at least three months during winter. Some of the stations on ice were tilted, probably due to heat production of the active seismometers and therefore lost the horizontal components after around four to five months. After the deployment described here, the GLISN project has obtained improved performance by using insulating foam instead of wooden plates. The stations were maintained annually during the summers.

Data acquisition was enabled by grants to HT from Research Council for Nature and Universe and the Carlsberg Foundation. The data have been acquired in order to carry out a suite of seismological interpretations with, for example, seismic body and surface wave tomography. Acquisition involved the use of a Twin Otter airplane for the initial deployment of the broadband stations on the ice sheet, helicopters to reach the remote locations on bed rock, and primarily snow mobiles on expeditions for maintenance and recovery of the stations on the ice sheet, by small groups led by HT. The data will become publicly available.

For the interpretation, we have further included data from four stations (DBG, ICESG, SCO, SUMG) of the GLISN network (Clinton et al., 2014) and HJO of the GLATIS project (Dahl-Jensen et al., 2003; Table 1 and Figure 2).

For compilation of a Moho map we included the results from another receiver function study based on data from 10 stations in the northern part of the study area (Schiffer et al., 2014) as well as the results from several refraction experiments in the fjords of eastern Greenland (Mandler, 1995; Schmidt-Aursch \& Jokat, 2005) and the only existing onshore active-source seismic profile on the ice sheet along part of our main profile at $70^{\circ} \mathrm{N}$ (Shulgin \& Thybo, 2015).

Data for events with magnitudes greater than 5.4 and epicentral distances between $35^{\circ}$ and $90^{\circ}$ were cut out of the continuous seismological data and visually inspected for quality control. In general, the stations on ice show a much higher signal-to-noise ratio than the stations on bedrock, which were close to the coast and therefore subject to strong noise level from the Atlantic Ocean.

\section{2. $P$ Receiver Functions}

We calculate $P$ receiver functions (PRF), which utilize the difference in travel times between direct $P$ and their corresponding $S$ phases that have been converted and reflected at discontinuities following the approach of Vinnik (1977). We rotate the seismograms using the back azimuth and measured apparent incidence angle into an LQT coordinate system to separate the $P$ and $S$ wave energy. The $L$ axis is parallel to the principal particle motion of direct $P$, and hence contains mainly $P$ wave energy. Axis $Q$ is normal to $L$ in the wave propagation plane and includes the SV motion. Axis $T$ is perpendicular to the $L$ and $Q$ axes and corresponds to the $\mathrm{SH}$-wave motion (horizontally polarized $S$ wave). To equalize and remove source effects the $Q$ and $T$ components are deconvolved by a time domain spiking filter derived from the $L$ component. The deconvolution is performed in the time domain by the technique of Berkhout (1977). Application of this technique for calculation of PRF assumes that the $P$ waveform which is used for deconvolution consists of 
Table 1

Station Locations, Used Residuals, and Moho Depth Below Surface

\begin{tabular}{|c|c|c|c|c|c|c|c|c|c|}
\hline \multirow[b]{2}{*}{ Station } & \multicolumn{3}{|c|}{ Coordinates } & \multirow{2}{*}{$\begin{array}{c}\text { Ice } \\
\text { Thickness }\end{array}$} & \multicolumn{2}{|c|}{ Number of Events } & \multicolumn{2}{|c|}{ Residuals } & \multirow{2}{*}{$\begin{array}{l}\text { Moho } \\
\text { Depth }\end{array}$} \\
\hline & Latitude & Longitude & Altitude & & PRF & $\mathrm{SRF}$ & $\Delta t_{p}$ & $\Delta t_{s}$ & \\
\hline \multirow[t]{2}{*}{ STA02 + STA03 } & $70.14^{\circ} \mathrm{N}$ & $23.089^{\circ} \mathrm{W}$ & $513 \mathrm{~m}$ & & $26(8+18)$ & $37(20+17)$ & $-0.1 \mathrm{~s}$ & $-0.3 \mathrm{~s}$ & $14 \pm 4 \mathrm{~km}$ \\
\hline & $70.15^{\circ} \mathrm{N}$ & $23.946^{\circ} \mathrm{W}$ & $854 \mathrm{~m}$ & & & & & & \\
\hline STA04 & $70.255^{\circ} \mathrm{N}$ & $24.892^{\circ} \mathrm{W}$ & $543 \mathrm{~m}$ & & 14 & 16 & $-0.125 \mathrm{~s}$ & $-0.375 \mathrm{~s}$ & $24 \pm 4 \mathrm{~km}$ \\
\hline STA06 & $70.304^{\circ} \mathrm{N}$ & $26.881^{\circ} \mathrm{W}$ & $457 \mathrm{~m}$ & & 14 & 20 & $0.25 \mathrm{~s}$ & $0.75 \mathrm{~s}$ & $35 \pm 4 \mathrm{~km}$ \\
\hline \multirow[t]{3}{*}{ STA07 + HJO + STA09 } & $70.336^{\circ} \mathrm{N}$ & $27.881^{\circ} \mathrm{W}$ & $1083 \mathrm{~m}$ & & $34(11+9+14)$ & $34(12+9+13)$ & $1.5 \mathrm{~s}$ & $4.5 \mathrm{~s}$ & $42 \pm 4 \mathrm{~km}$ \\
\hline & $70.35^{\circ} \mathrm{N}$ & $28.16^{\circ} \mathrm{W}$ & $40 \mathrm{~m}$ & & & & & & \\
\hline & $70.446^{\circ} \mathrm{N}$ & $30.089^{\circ} \mathrm{W}$ & $1845 \mathrm{~m}$ & & & & & & \\
\hline \multirow{2}{*}{ STA11 + STA12 } & $70.548^{\circ} \mathrm{N}$ & $31.579^{\circ} \mathrm{W}$ & $2666 \mathrm{~m}$ & $1460 \mathrm{~m}$ & $35(12+23)$ & $29(10+19)$ & $0.4 \mathrm{~s}$ & $1.2 \mathrm{~s}$ & $42 \pm 4 \mathrm{~km}$ \\
\hline & $70.599^{\circ} \mathrm{N}$ & $32.538^{\circ} \mathrm{W}$ & $2811 \mathrm{~m}$ & $1830 \mathrm{~m}$ & & & & & \\
\hline STA13 & $70.621^{\circ} \mathrm{N}$ & $33.497^{\circ} \mathrm{W}$ & $2931 \mathrm{~m}$ & $2270 \mathrm{~m}$ & 20 & 13 & $-0.1 \mathrm{~s}$ & $-0.3 \mathrm{~s}$ & $42 \pm 4 \mathrm{~km}$ \\
\hline \multirow[t]{2}{*}{ STA14 + STA15 } & $70.648^{\circ} \mathrm{N}$ & $34.478^{\circ} \mathrm{W}$ & $3008 \mathrm{~m}$ & $2520 \mathrm{~m}$ & $29(10+19)$ & $20(8+12)$ & $0.4 \mathrm{~s}$ & $1.2 \mathrm{~s}$ & $42 \pm 4 \mathrm{~km}$ \\
\hline & $70.671^{\circ} \mathrm{N}$ & $35.425^{\circ} \mathrm{W}$ & $3076 \mathrm{~m}$ & $2790 \mathrm{~m}$ & & & & & \\
\hline STA16 & $70.685^{\circ} \mathrm{N}$ & $36.379^{\circ} \mathrm{W}$ & $3123 \mathrm{~m}$ & $2980 \mathrm{~m}$ & 18 & 18 & $0.7 \mathrm{~s}$ & $2.1 \mathrm{~s}$ & $43 \pm 3$ \\
\hline STA17 & $70.679^{\circ} \mathrm{N}$ & $37.325^{\circ} \mathrm{W}$ & $3152 \mathrm{~m}$ & $3080 \mathrm{~m}$ & 18 & 17 & $0.5 \mathrm{~s}$ & $1.5 \mathrm{~s}$ & $45 \pm 3 \mathrm{~km}$ \\
\hline STA18 & $71.637^{\circ} \mathrm{N}$ & $38.291^{\circ} \mathrm{W}$ & $3164 \mathrm{~m}$ & $3290 \mathrm{~m}$ & 23 & 18 & $0.75 \mathrm{~s}$ & $2.25 \mathrm{~s}$ & $38 \pm 5 \mathrm{~km}$ \\
\hline STA19 & $72.233^{\circ} \mathrm{N}$ & $32.909^{\circ} \mathrm{W}$ & $2860 \mathrm{~m}$ & $2550 \mathrm{~m}$ & 12 & 5 & $-0.2 \mathrm{~s}$ & $-0.6 \mathrm{~s}$ & $38 \pm 4 \mathrm{~km}$ \\
\hline STA20 & $71.564^{\circ} \mathrm{N}$ & $33.028^{\circ} \mathrm{W}$ & 3164 m & $2260 \mathrm{~m}$ & 15 & 9 & $0.6 \mathrm{~s}$ & $1.8 \mathrm{~s}$ & $29 \pm 5 \mathrm{~km}$ \\
\hline STA22 & $71.944^{\circ} \mathrm{N}$ & $27.987^{\circ} \mathrm{W}$ & $1263 \mathrm{~m}$ & & 19 & 28 & $0.1 \mathrm{~s}$ & $0.3 \mathrm{~s}$ & $48 \pm 4 \mathrm{~km}$ \\
\hline STA24 & $71.369^{\circ} \mathrm{N}$ & $24.891^{\circ} \mathrm{W}$ & $224 \mathrm{~m}$ & & 23 & 30 & $0.95 \mathrm{~s}$ & $2.85 \mathrm{~s}$ & $24 \pm 4 \mathrm{~km}$ \\
\hline DBG & $74.31^{\circ} \mathrm{N}$ & $20.22^{\circ} \mathrm{W}$ & $10 \mathrm{~m}$ & & 122 & 56 & $0.4 \mathrm{~s}$ & $1.2 \mathrm{~s}$ & $21 \pm 4 \mathrm{~km}$ \\
\hline ICESG & $69.09^{\circ} \mathrm{N}$ & $39.65^{\circ} \mathrm{W}$ & $2932 \mathrm{~m}$ & $2500 \mathrm{~m}$ & 114 & 59 & $0.1 \mathrm{~s}$ & $0.3 \mathrm{~s}$ & $32 \pm 4 \mathrm{~km}$ \\
\hline $\mathrm{SCO}$ & $70.48^{\circ} \mathrm{N}$ & $21.95^{\circ} \mathrm{W}$ & $69 \mathrm{~m}$ & & 73 & 91 & $1.0 \mathrm{~s}$ & $3.0 \mathrm{~s}$ & $28 \pm 3 \mathrm{~km}$ \\
\hline SUMG & $72.58^{\circ} \mathrm{N}$ & $38.45^{\circ} \mathrm{W}$ & $3275 \mathrm{~m}$ & $3050 \mathrm{~m}$ & 334 & 262 & $0.9 \mathrm{~s}$ & $2.7 \mathrm{~s}$ & $51 \pm 5 \mathrm{~km}$ \\
\hline
\end{tabular}

Note. Uncertainties of Moho depth are estimated by visual inspection of the velocity inversion results.

signal and noise. A damping parameter of 3 is found by trial and error to account for the noise and is used to minimize the distortion.

In the case of a seismically isotropic medium there is no converted $\mathrm{SH}$ phase. We do not observe strong signals on the $T$ component and hence no indication for strong anisotropy and lateral heterogeneity. Our further analysis is based on the $Q$ component. In order to improve the signal-to-noise ratio, we applied stacking where we assume a reference slowness of $6.4 \mathrm{~s} / \mathrm{deg}$, which corresponds to an epicentral distance of $67^{\circ}$.

The PRFs are band-pass filtered with corner periods of 30 and $2 \mathrm{~s}$. Additional low-pass filtering with different corner frequencies was tested after the initial stacking. We find that a 5-s low-pass filter provides the clearest results, which indicates a picking uncertainty of approximately $0.5 \mathrm{~s}$, corresponding to approximately $4-\mathrm{km}$ vertical resolution.

The number of useful events per station varies from 8 for STA02 to over 300 for the permanent station SUMG, which provides data for more than 10 years. To achieve a sufficient number of events per stack, we summed in some cases the signals from two or three neighboring, temporary stations. The back azimuths of the events available for processing are primarily in a northerly and a south-westerly direction with a few events from an easterly direction (Figure 3).

The single-event PRFs are moveout-corrected for the reference slowness before stacking all events for each station in order to enhance the signal-to-noise ratio. All single-event PRFs were visually checked and only those with a high signal-to-noise ratio were kept for further processing. The maximum distance from the conversion points at Moho to each station are around $6 \mathrm{~km}$ for the eastern stations, where the Moho dips approximately $10^{\circ}$ maximum, and around $14 \mathrm{~km}$ for the westernmost stations where there is very little variation in Moho topography. This justifies the application of our stacking procedures, as the maximum variation in Moho depth for the stacked traces for STA2 and STA3 is about $1.7 \mathrm{~km}$, which is well within our estimated uncertainty. Likewise, the stacking of STA7 with STA9 and HJO includes an altitude variation of $1,800 \mathrm{~m}$, which is within the estimated uncertainty of $4 \mathrm{~km}$. In case the $\mathrm{S} / \mathrm{N}$ ratio of the data would 


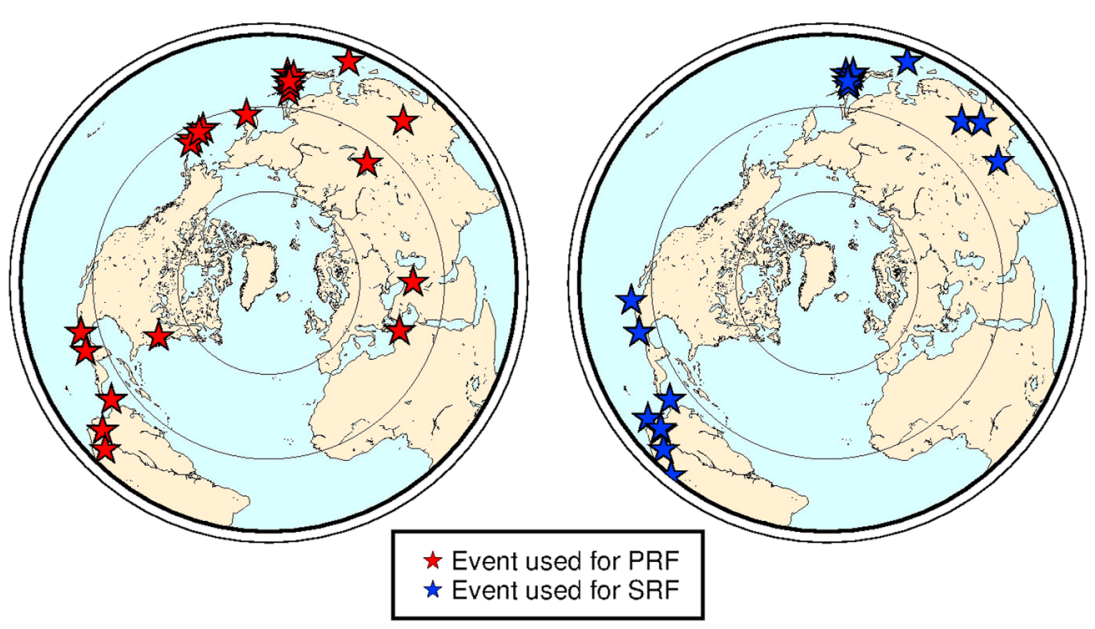

Figure 3. Event distribution for STA18, for $P$ (left) and $S$ (right) receiver functions. Each star marks the epicenter location of an event used in the RF calculation. The concentric circles mark $30^{\circ}, 60^{\circ}$, and $90^{\circ}$ epicentral distance to the center of the array.

have been better we could have opted for using single station inversion of the receiver functions, but the available data do not allow such procedure due to the noise level.

The resulting PRFs show clear Moho conversions for stations on bedrock, whereas the PRF Moho signal for the ice stations is masked by strong reverberative arrivals from multiples generated in the ice cover (Figure 4).

\section{3. $S$ Receiver Functions}

The $S$ receiver function (SRF) method utilizes $S$ to $P$ converted phases. A main advantage of this method is that the multiples do not interfere with the signal of the SRF (the $S p$ phases), because it arrives earlier than the direct $S$ wave, while the multiples arrive later. For SRF calculations we select events with an epicentral distance between $65^{\circ}$ and $90^{\circ}$ and rotate the seismograms into a QLT coordinate system, where the $Q$ axis is parallel to the $S$ wave particle motion in the wave propagation plane and corresponds to the SV movement. The $L$ axis is perpendicular to $Q$ and in the same plane. The $L$ component contains only $P$ energy and is therefore used to detect the $S p$ converted phases. $T$ is perpendicular to the wave propagation plane. Similar to the PRF, spiking deconvolution is applied with a damping parameter of 3. In an isotropic Earth the $S p$ phase is generated by the SV component. In the case of anisotropy, $S p$ phases also originate from the SH component (horizontally polarized $S$ wave). To enhance the effect of SV converted phases and to increase the signal-to-noise ratio, the SRFs are stacked with a weighting factor according to the noise level in the interval from -60 to $-20 \mathrm{~s}$. For the SRF we use a band-pass filter with corner frequencies of 30 and 8 s. Further details regarding the method are described by Farra and Vinnik (2000).

All $S$ receiver functions show clear conversions from the Moho (Figure 4) also for stations on the ice sheet.

\subsection{Inversion}

We calculate velocity models from our data by simultaneous inversion of the PRFs and SRFs under the assumption of a laterally homogeneous and isotropic Earth in the vicinity of the station. Each inversion is run for four independent, random starting models within specified allowed limits. The optimal models are found by an iterative procedure similar to the simulated annealing approach by Mosegaard and Vestergaard (1991). In this technique, the misfit between the actual and synthetic functions is minimized by forming a set of model perturbations. The misfit (cost) is defined as the RMS difference between the recorded and synthetic components of the receiver functions.

The models are defined by $V_{p}, V_{s}$, and layer thickness with a maximum of nine layers, where density is derived from $V_{p}$ by application of Birch's law. An Earth flattening transformation is applied according to 

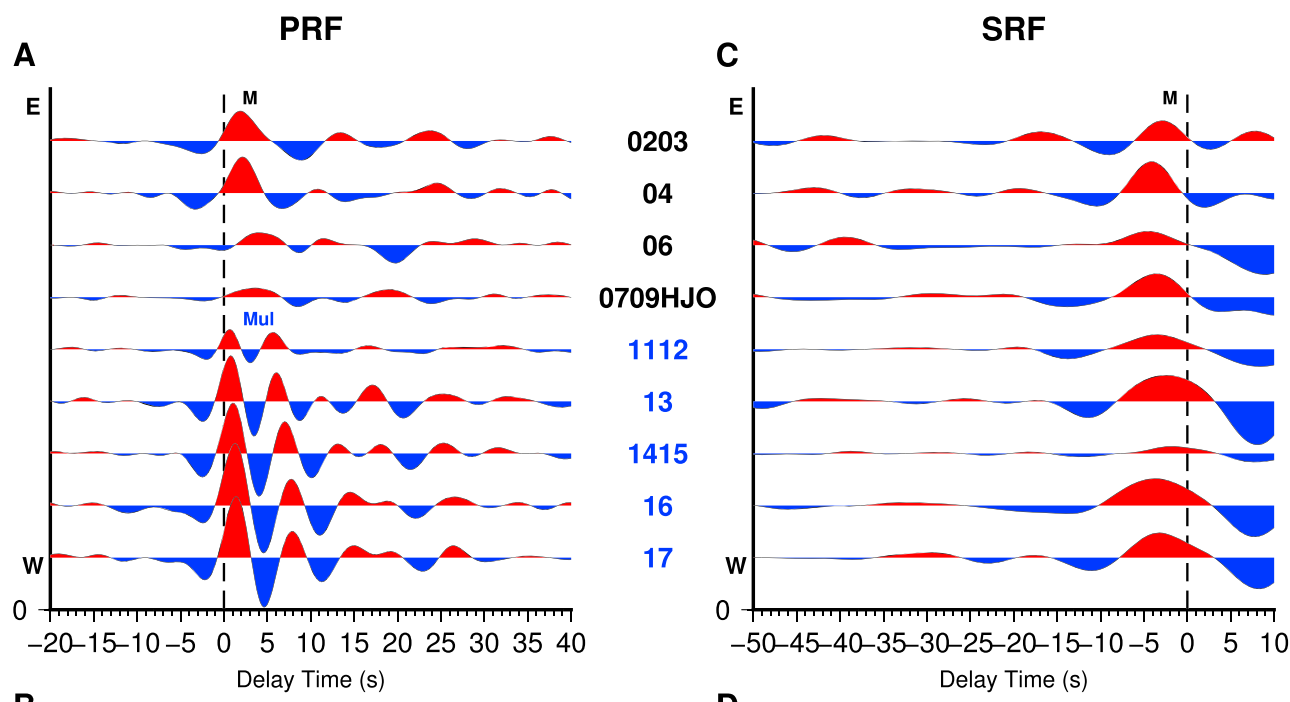

B
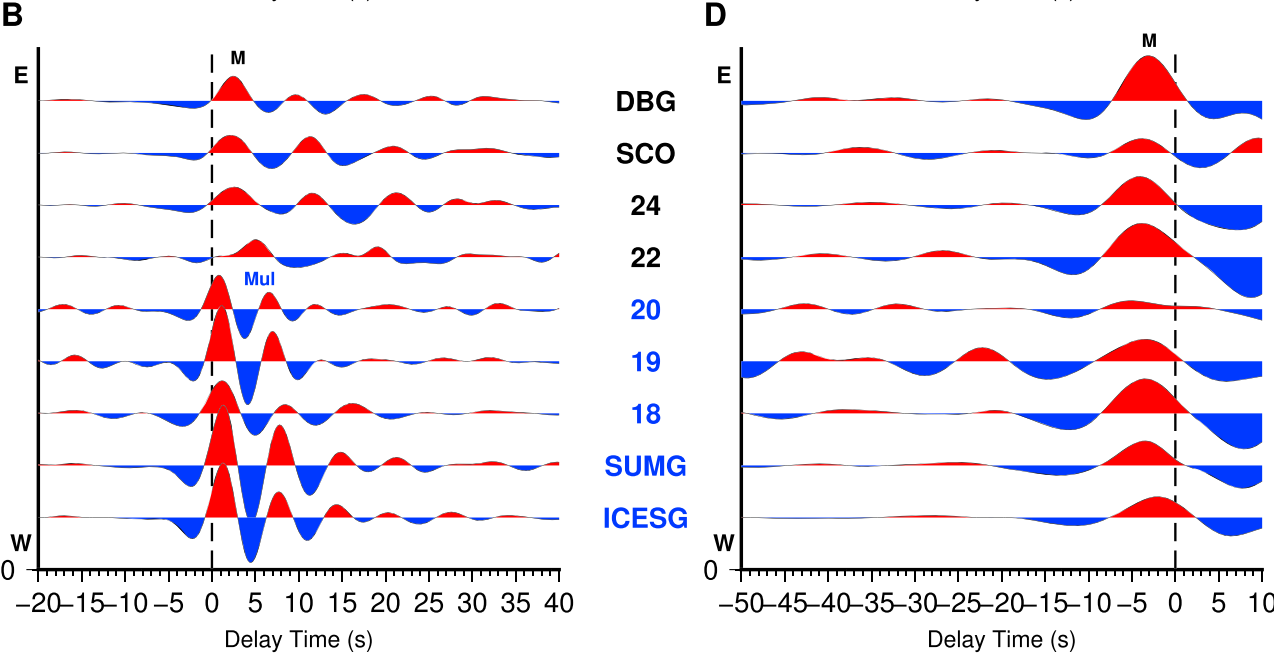

Figure 4. (a and c) $P$ and $S$ receiver functions for stations along the profile at $70^{\circ} \mathrm{N}$ and (b and d) outside the main profile. Red/blue amplitudes relate to conversions from a positive/negative velocity discontinuity. The signal-to-noise level is high. The stations on bedrock (black labels) show clear Moho $P$ and $S$ conversions at times of 2 to $6 \mathrm{~s}$ (marked with M), with gradually increasing delay time from east to west. The stations on ice (blue labels), however, show very different characteristics, including a stronger negative amplitude before 0 time than stations on bedrock which is most likely a sidelobe of the conversion at the bottom of the ice. The first $15 \mathrm{~s}$ of the PRFs are dominated by high-amplitude conversions from the interface between ice and bedrock and their multiples (marked with Mul). This includes the time interval, where we expect the signal from the Moho. Its amplitude is smaller and it is therefore masked by the ice reverberations. However, the SRF shows clear conversions from the Moho $(\mathrm{M})$, because they arrive before the ice multiples.

Biswas (1972). This technique assumes similar slowness for the $P$ wave and the converted $P$ s phases in the same recording. The actual difference can be neglected for relatively small depths (less than $\sim 300 \mathrm{~km}$ ) and long periods (more than $\sim 5 \mathrm{~s}$ ).

The inversion iteratively modifies the model to minimize the RMS misfit between the observed and synthetic RFs calculated with a Thomson-Haskell matrix algorithm for plane waves and horizontal interfaces (Haskell, 1962). This is done simultaneously for PRF and SRF. For each starting point, $10^{5}$ models are calculated and the last 10,000 are kept. These numbers are sufficient for the trial models to converge to those providing a small misfit between the actual and modeled components of the receiver functions. The last $5 \%$ of the trial models are used to evaluate the posterior distribution of the model parameters near the misfit minimum. For visualization the parameter space is divided into cells and the number of hits per cell is shown by a color code. We present similar statistics for synthetic receiver functions. A comparison of this statistics with the actual receiver functions demonstrates the quality of the fit. Further information regarding the inversion 
code is provided by Vinnik et al. (2006) and Kiselev et al. (2008). Our study is the first application of this method to data from an ice sheet.

Additional input parameters are the mantle travel time residuals for the $P$ and $S$ waves in comparison to IASP91 (Kennett \& Engdahl, 1991). We obtain these residuals from the delay times of the mantle transition zone signals P410s and P660s (Kraft et al., 2018). The inversion is calculated to a depth of $300 \mathrm{~km}$, but here we show the results only to a depth of $70 \mathrm{~km}$, since we are focusing on the crustal structure. As noted by Silveira et al. (2010), the apparent incidence angle of the $P$ wave depends on the crustal $S$ wave velocity, whereas that of the $S$ wave depends on both $P$ and $S$ wave crustal velocities. Both angles are measured in the actual recordings to rotate the axes and both are used in the inversion procedure. As a result, the absolute values of the $P$ and $S$ velocities and their ratio are constrained in the inversion procedure. The inversion result can be further constrained by teleseismic $P$ and $S$ wave travel time residuals $\left(\Delta t_{p}\right.$ and $\left.\Delta t_{s}\right)$ with respect to IASP91. These residuals are obtained from the residuals of the converted phases P410s or P660s $(\Delta \mathrm{Tp} 410 \mathrm{~s}$ and $\Delta$ tp660s) under the assumption that the residuals are accumulated in the depth range of the model (from 0 to $300 \mathrm{~km}$ ). This is justified if the differential time between P660s and P410s is close to the standard value (23.9 s), which indicates that the 660- and 410-km boundaries are located at their standard depths and the residuals of P410s and P660s present the effect of volumetric velocity anomalies in the crust and the upper mantle. In this case, $\Delta \mathrm{tP} 410 \mathrm{~s}=\Delta t_{s}-\Delta t_{p}$, where $\Delta t_{p}$ and $\Delta t_{s}$ can be determined from their ratio $\Delta t_{s} / \Delta t_{p}$. A typical value of this ratio is close to 3 (Vinnik et al., 1999).

In eastern central Greenland the differential time often deviates from the standard value (Kraft et al., 2018) and accurate values of the residuals related to the crust and upper mantle are to some extent uncertain. This made us perform inversion with trial values of the residuals. In general, the resulting overall crustal structure is independent of the residuals used (Figure 5) regarding both Moho depth and crustal velocities. The results were selected based on the distinctness of the velocity models. As shown by the width of the highdensity parts of the posterior distributions, the resulting $S$ wave velocities are more accurate than the $P$ wave velocities. The accuracy of the $V_{p} / V_{s}$ ratio is sometimes sufficient to observe systematic variations of this ratio with depth. We therefore use mainly the $V_{s}$ model for our further analysis.

For the stations on ice, the thickness and the velocities of the ice were given as fixed a priori input parameters (Amante \& Eakins, 2009; Wittlinger \& Farra, 2012). Although the Moho signal in the PRF is contaminated by reverberations from inside the ice, we obtain clear results for the crustal structure from the joint inversion of PRF and SRF for the ice stations, mainly because the relevant parts of the $S$ receiver functions are unaffected by ice multiples.

\section{Results}

\subsection{Example Stations}

To illustrate the quality of the receiver function inversion, we discuss the inversion results in detail for two stations on the ice sheet and two stations that were located on bedrock. Stations STA13 (Figure 5b) and SUMG (Figure 6a) were operating on 2,270- and 3,050-m-thick ice. The ice layer was given as an a priori input to the inversion procedure with $V_{p}=3.8 \mathrm{~km} / \mathrm{s}$ and $V_{s}=1.8 \mathrm{~km} / \mathrm{s}$, as seen on top of all three resulting models $\left(V_{p}, V_{s}\right.$, and $\left.V_{p} / V_{s}\right)$.

STA 13 (Figure 5b) shows a stable high $V_{s}$ of around $3.75 \mathrm{~km} / \mathrm{s}$ in the crust. The relatively constant value through the whole crust is surprising, in particular the high $V_{S}$ in the upper crust, but it is a well-constrained observation, as also indicated by the narrow central part of the velocity contours from the inversion. $V_{p}$ is a more uncertain parameter than $V_{s}$ in RF inversion. Whether the very high $V_{p}$ of around 6.5 to $7 \mathrm{~km} / \mathrm{s}$ directly underneath the ice is a real feature or an artifact of the ice is unclear. At a depth of around $28 \mathrm{~km}$ there is a positive jump in $V_{p}$ from 6.1 to $7.1 \mathrm{~km} / \mathrm{s}$ and an increase of $V_{p} / V_{s}$ from 1.6 to 1.8. A clear converter is observed in all three models at approximately $42 \mathrm{~km}$ with velocity jumps to 7.9 and $4.65 \mathrm{~km} / \mathrm{s}$, which we interpret as the Moho.

The inversion results for station SUMG (Figure 6a) are based on a large amount of data as this station has been operating for a period of more than 10 years. Again the ice layer was given as fixed input. The upper crust appears to have a very high $V_{p}$ of approximately $6.8 \mathrm{~km} / \mathrm{s}$ and a $V_{s}$ of approximately $3.75 \mathrm{~km} / \mathrm{s}$ corresponding a $V_{p} / V_{s}$ of 1.8. There is indication for a possible interface at around 12-km depth. There is a clear 

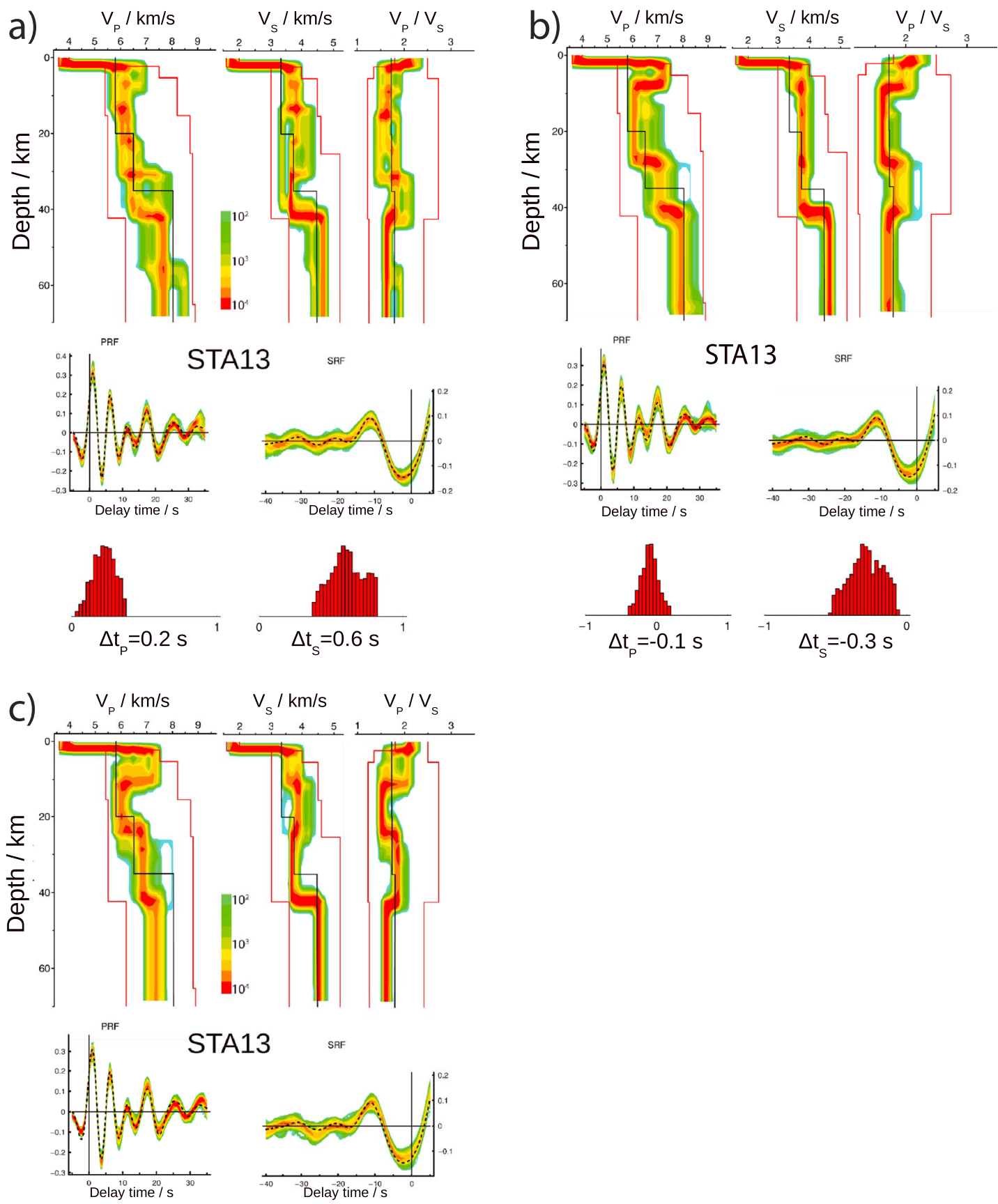

STA13 SAF
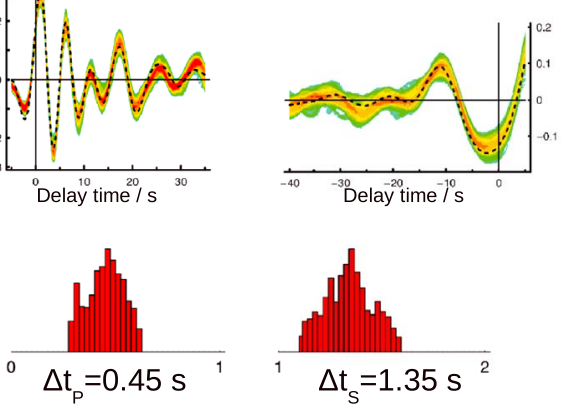

Figure 5. Inversion results for STA13 with three different sets of travel time residuals. Each figure consists of the resulting $V_{p}$ and $V_{S}$ model, the corresponding $V_{p} / V_{S}$ ratio, the input PRF and SRF (dashed line) together with the synthetic RFs based on the velocity models, and a plot showing statistics for the travel time residuals for the calculated models. The color coding in both models and the synthetic RF shows the number of the $10^{5}$ calculated models (or synthetic RF) that hit the respective point. The red lines in $V_{p}, V_{S}$, and $V_{p} / V_{S}$ show the depth-dependent upper and lower limits of velocity of the allowed solution space. The black line shows the IASP91 model for comparison. The three sets of residuals are (a) $\Delta t_{p}=0.2 \mathrm{~s}, \Delta t_{s}=0.6 \mathrm{~s}$; (b) $\Delta t_{p}=-0.1 \mathrm{~s}, \Delta t_{s}=-0.3 \mathrm{~s}$; and (c) $\Delta t_{p}=0.45 \mathrm{~s}$, $\Delta t_{s}=1.35 \mathrm{~s}$. All three sets of residuals lead to the same Moho depth (approximately $42 \mathrm{~km}$ ) and the crustal velocities are similar. The models for $\Delta t_{p}=-0.1 \mathrm{~s}$, $\Delta t_{s}=-0.3 \mathrm{~s}$ and $\Delta t_{p}=0.45 \mathrm{~s}, \Delta t_{s}=1.35 \mathrm{~s}$ both show clear results, but the fit for SRF is slightly better in Figure $5 \mathrm{~b}$ and the hit count for the $P$ residual has a more regular shape, which is the reason that we chose $\Delta t_{p}=-0.1 \mathrm{~s}, \Delta t_{s}=-0.3 \mathrm{~s}$. 
a)
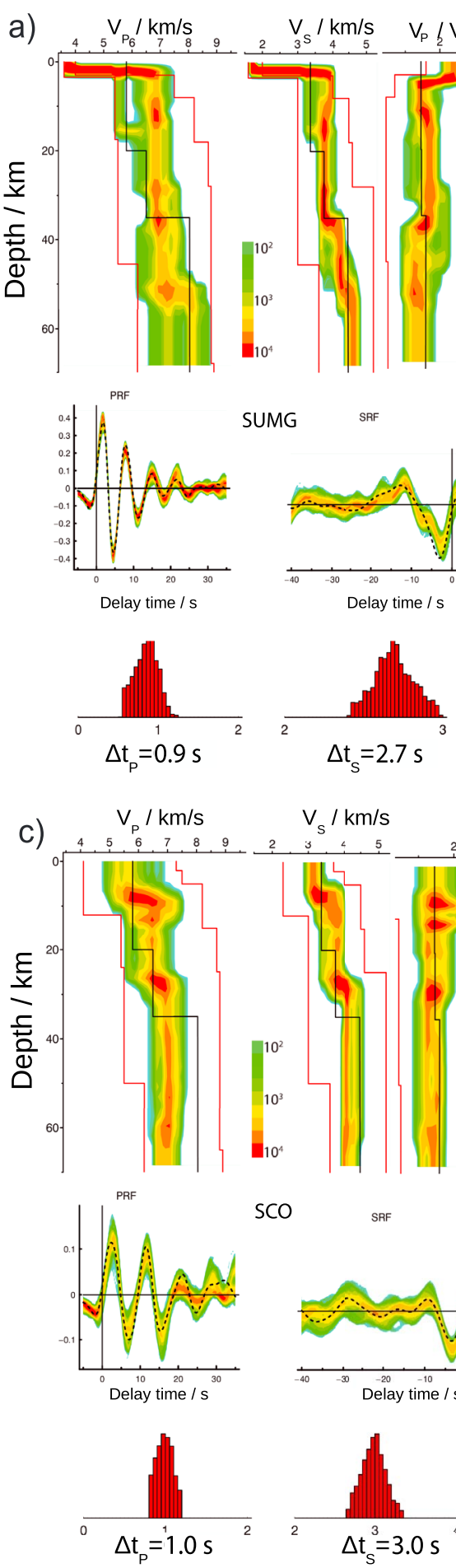

SCO SRF

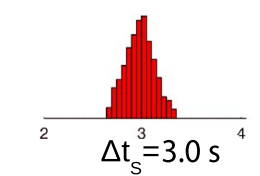

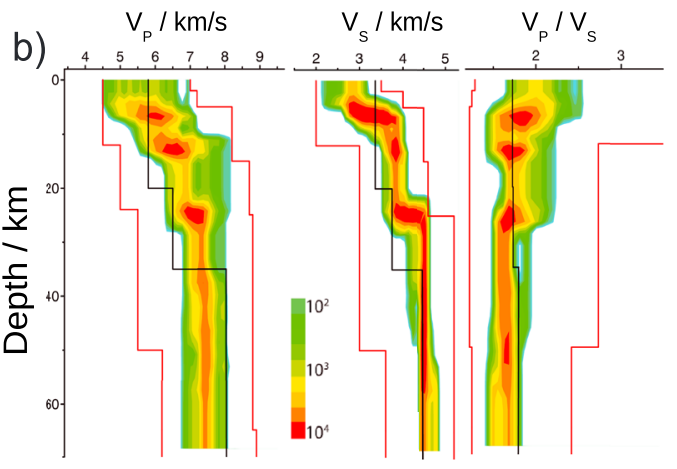

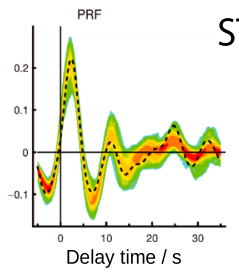

STA04 SPF
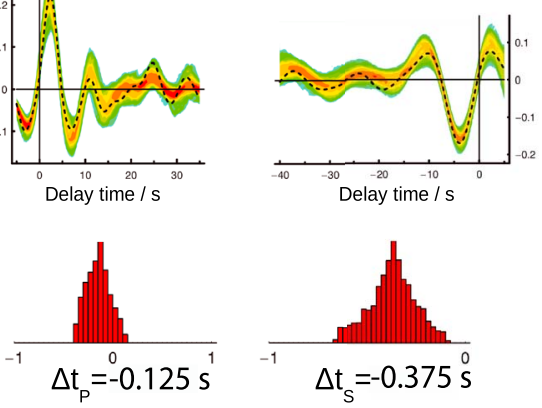
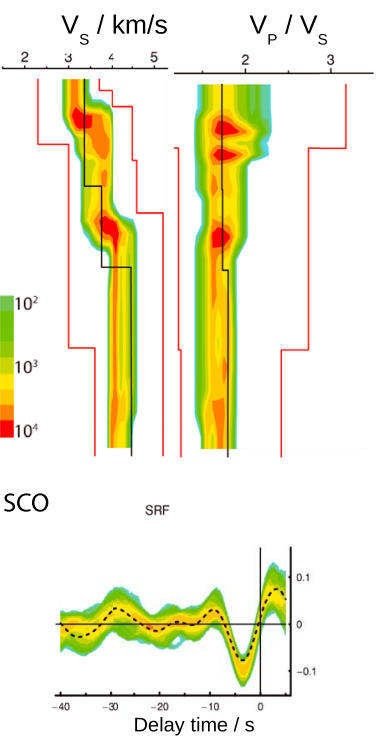

Figure 6. Examples of the inversion results for stations (a) SUMG, (b) STA04, and (c) SCO. See Figure 5 for figure description. Similar plots are shown for all stations in the supporting information.

discontinuity at around $37 \mathrm{~km}$ to velocities of 7.0 and $4.2 \mathrm{~km} / \mathrm{s}$ and a surprisingly low $V_{p} / V_{s}$ of 1.7 . We interpret the clear jump to a $V_{p}$ of $8.0 \mathrm{~km} / \mathrm{s}$ and the gradual jump to $4.6 \mathrm{~km} / \mathrm{s}$ in $V_{s}$ at around $51 \mathrm{~km}$ to be the Moho. The fit between the observed and the synthetic PRFs is very good and even the internal reverberations from inside the ice are very well reproduced. 
STA04 (Figure 6b) was installed on bedrock on the profile along $70^{\circ} \mathrm{N}$. We find only $14 / 16$ events of sufficiently high quality for calculation of PRF/SRF. Despite the small number of events, the inversion shows very clear results, as demonstrated by the fit between observed and synthetic RFs and the regularly shaped residual histograms. A characteristic thin low-velocity layer is identified in the uppermost crust with a thickness of approximately $7 \mathrm{~km}$ and $V_{s}<3 \mathrm{~km} / \mathrm{s}$ as well as a high $V_{p} / V_{s}$ of 2 . Below this low-velocity layer the velocities are $V_{s}=3.75 \mathrm{~km} / \mathrm{s}$ and $V_{p}=6.9 \mathrm{~km} / \mathrm{s}$, resulting in an $V_{p} / V_{s}$ of 1.84 . At a depth of $25 \mathrm{~km}$ there is a clear converter with jumps to 4.5 and $7.5 \mathrm{~km} / \mathrm{s}$, respectively, which we interpret as the Moho. The depth of $25 \mathrm{~km}$ is in agreement with results by Schmidt-Aursch and Jokat (2005) from a wide-angle reflection and refraction profile in the fjord a few kilometers north of STA04. These authors observe a steep dip of the Moho to the west of STA04, and therefore, we choose to not combine the data of STA04 with data from neighboring stations.

Station SCO (Figure 6c) operates also on bedrock in Scoresbysund approximately $50 \mathrm{~km}$ north of STA04 on the other side of Scoresbysund Fjord. For SCO we could use data from a five-year-long period and also here the fit between observed and synthetic RFs is good. The inversion results indicate also here the presence of a low-velocity layer at the top of the crust with a thickness of $8 \mathrm{~km}$. In contrast to STA04, the $V_{p}$ of approximately $5.5 \mathrm{~km} / \mathrm{s}$ and the $V_{s}$ of $3.1 \mathrm{~km} / \mathrm{s}$ are both relatively low and the $V_{p} / V_{s}$ of approximately 1.75 is small and much smaller than for STA04. Below this layer we observe crust with stable $V_{p}=6.5 \mathrm{~km} / \mathrm{s}$ and $V_{s}=3.75 \mathrm{~km} / \mathrm{s}$ down to a clear converter at $28 \mathrm{~km}$, which we interpret as the Moho in agreement with $28 \mathrm{~km}$ from Dahl-Jensen et al. (2003) and $27 \mathrm{~km}$ from Kumar et al. (2007). Figures showing the inversion results for all stations of the array are shown in the supporting information.

\subsection{Crustal Structure of the Study Area}

The resulting $V_{S}$ models from all the inversions (Figure 7) show a clear variation in crustal thickness in the area from a very thin crust (less than $20 \mathrm{~km}$ thick) in the eastern part of the study area to 50 -km-thick crust in central Greenland. For the 5-30-s period band, corresponding to wavelengths larger than $40 \mathrm{~km}$, we find that the picking uncertainty of arrivals is around $4 \mathrm{~km}$, which is also the uncertainty we estimate by visual inspection of the inversion results.

Along the profile at $70^{\circ} \mathrm{N}$ (Figures 7 and 8, upper profile), we observe a relatively steep deepening of Moho over a distance of approximately $170 \mathrm{~km}$ from a depth of $14 \mathrm{~km}$ at STA02 + STA03 to $42 \mathrm{~km}$ at STA07 + HJO + STA09. Further westward the Moho deepens gradually to $44 \mathrm{~km}$ at STA17 without much change in the $V_{s}$ profile, although stations STA07 + HJO + STA09 and STA16 show a tendency for elevated lower crustal $V_{s}$ with constant $V_{p} / V_{s}$. Stations STA11 + STA12, STA13, and STA14 + STA15 are located close to each other in the central part of the study area. They do not show elevated $V_{s}$ but instead include elevated $V_{p} / V_{s}$ in the lower crust. These two observations indicate that a distinct lower crust is present below most of the ice sheet along this profile. The easternmost stations show low $V_{S}$ in the uppermost crust.

The other stations in the study area (Figures 7 and 8, lower profile) do not follow a linear profile, but have been ordered according to longitude. They show a shallow Moho $(22-28 \mathrm{~km}$ ) at the coast (DBG, SCO, STA24) followed by some undulation between $44 \mathrm{~km}$ at STA22 and $32 \mathrm{~km}$ at STA18/STA19, as the deepest converter identified in the velocity models, and ICESG to the deepest Moho in the area of $51 \mathrm{~km}$ at SUMG. For STA20 we choose the deepest converter at approximately 44-km depth instead of the stronger converter at approximately $25 \mathrm{~km}$ because the nearby refraction seismic profile shows that the Moho is deep and because the Moho is substantially deeper than $25 \mathrm{~km}$ at STA19 as well as STA11 + 12 and STA13. The strong converter at approximately $25-\mathrm{km}$ depth must therefore represent the transition into the lower crust, and its strength may indicate that the lower crust has very high seismic velocity. The westernmost stations STA18, SUMG, and ICESG include high $V_{s}$ close to $4 \mathrm{~km} / \mathrm{s}$ in the lower crust below depths of 25-35 km without change in the $V_{p} / V_{s}$ ratio. These three stations are located further to west than the end of the $70^{\circ} \mathrm{N}$ profile, such that there is no discrepancy between the results along these two profiles.

The southernmost station, ICESG, shows triple layering: an upper crust, a low-velocity middle crust, and a high-velocity lower crust. We do not observe similar crustal layering at any other station, and ICESG is $200 \mathrm{~km}$ away from the nearest other station of our array. 

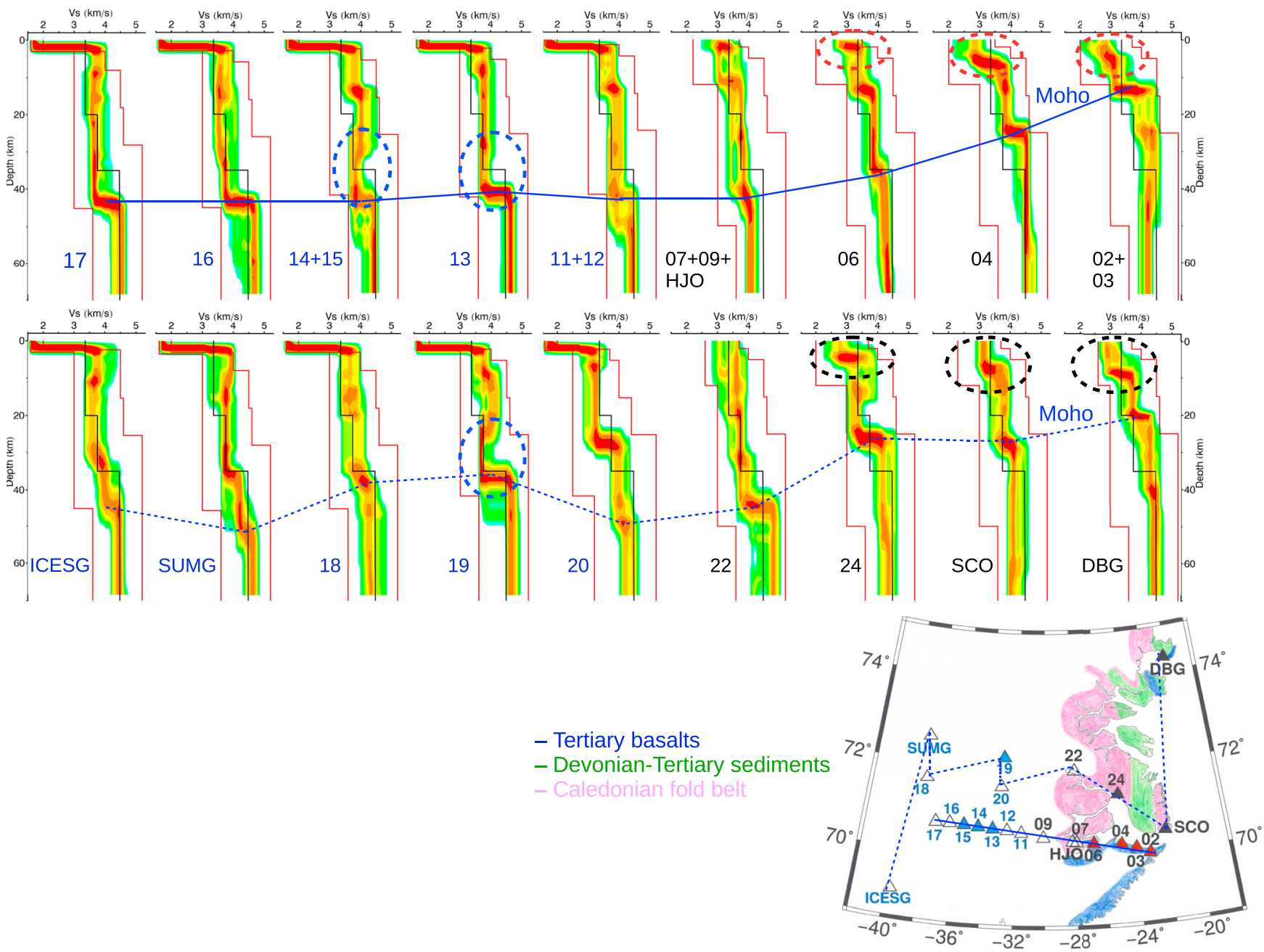

Figure 7. $V_{S}$ models for all stations. (top) Stations along the profile at $70^{\circ} \mathrm{N}$. (bottom) Stations outside the profile. The blue line connects the interface that we interpret as Moho. Blue labels = ice station, black label = bedrock station. Red ellipses: low-velocity layer on top with high $V_{p} / V_{s}$, black ellipses: low-velocity layer on top with normal $V_{p} / V_{S}$, cyan ellipses: low-velocity lower crust.

Some of the coastal stations (STA02 + 03, STA04, STA06, DBG, SCO, STA24) show a pronounced lowvelocity layer in the uppermost crust with $V_{s}<3 \mathrm{~km} / \mathrm{s}$ and a thickness between 3 and $10 \mathrm{~km}$ with thinning from east to west (marked with red and black ellipses). This low-velocity layer (Figure 8) has different characteristics to the south and north of Scoresbysund Fjord. The southern group has very high $V_{p} / V_{s}$ larger than 2 (STA02 + STA03, STA04, STA06; red ellipses) and the northern group has low to normal $V_{p} / V_{s}$ between 1.5 and 1.75 (DBG, SCO, STA24; black ellipses). The stations with high $V_{p} / V_{s}$ in the low-velocity layer are located on Tertiary basaltic rocks, while the stations with the low to normal $V_{p} / V_{s}$ are located in the region of the Caledonian fold belt and at the major sedimentary basin at Jameson Land.

The results indicate strong variability in $V_{p} / V_{s}$ ratio in the shallow crust for some of the stations that were deployed on the ice sheet. However, we have avoided interpreting these abrupt changes in uppermost crustal $V_{p} / V_{s}$ between neighboring stations because the influence of the presence of the ice layer may be very strong, whereas there are no similar effects for stations on bedrock.

\section{Discussion}

\subsection{Crustal Structure}

We have constructed a map of the depth to Moho in the study area (Figure 9) based on all the available data from the region. The overall trend includes a significant westward Moho deepening from the coast toward 

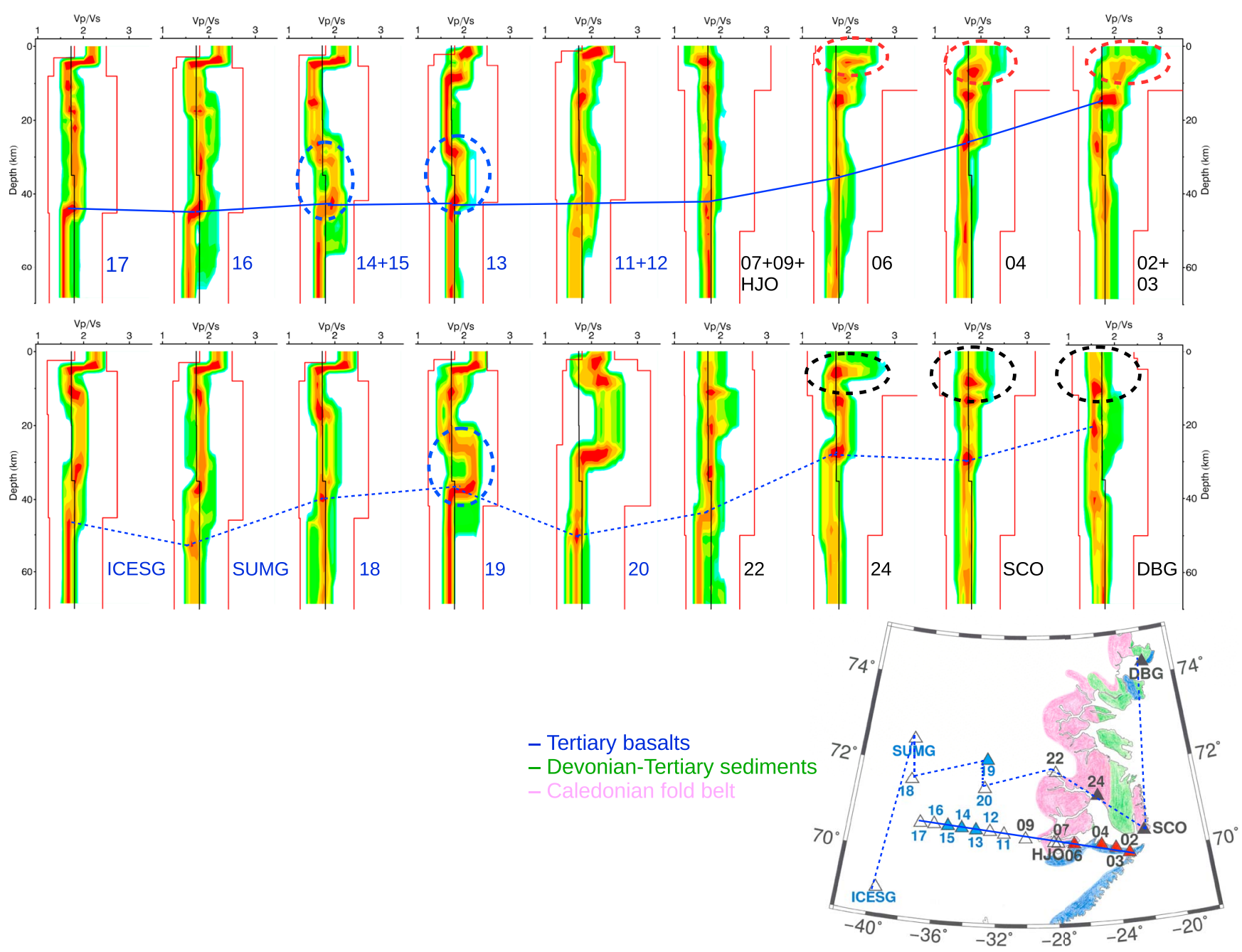

Figure 8. $V_{p} / V_{s}$ models for all stations. (top) Stations along the profile at $70^{\circ} \mathrm{N}$. (bottom) Stations outside the profile. The blue line connects the interface that we interpret as Moho. Blue labels = ice station, black label = bedrock station. Red ellipses: low-velocity layer on top with high $V_{p} / V_{s}$, black ellipses: low-velocity layer on top with normal $V_{p} / V_{s}$, cyan ellipses: low-velocity lower crust.

the center of Greenland without significant variation in the north-south direction and with only very little local deviation from the general trend.

The onshore southeastern part of the map has particularly thin crust at the northeastern edge of the large volcanic province related to NAIP where the crustal $V_{s}$ is also relatively high. The thin crust is surprising, as one would expect that magmatic addition to the crust, as indicated by the high $V_{p} / V_{s}$, would rather thicken the crust by underplating processes (Thybo \& Artemieva, 2013) than make it thinner. Thickening by underplating processes is also observed at the continental margins around the North Atlantic Ocean (Artemieva \& Thybo, 2013) and significant underplating is observed on the continental margin of Greenland further to the south (Dahl-Jensen et al., 1998). The crust on the Greenland-Iceland Ridge (in the offshore parts slightly further to the south) has double thickness of approximately $30 \mathrm{~km}$ and has been interpreted to be of oceanic origin (Holbrook et al., 2001). High mantle temperature in relation to the Iceland hot spot may have caused the formation of very thick oceanic crust (Reid \& Jackson, 1981; White et al., 1992), although there are unresolved aspects of this model (Artemieva \& Thybo, 2008). On this background the very thin crust in our area is not readily explainable. In the south, the formation of oceanic crust leads to very thick crust due to high mantle temperature and slightly further north high influx of mafic magma to the volcanic province results in thin crust. Thinning of the original continental crust may have played a role, but considering the very high $V_{s}$ and its likely relation to magma addition to the original 


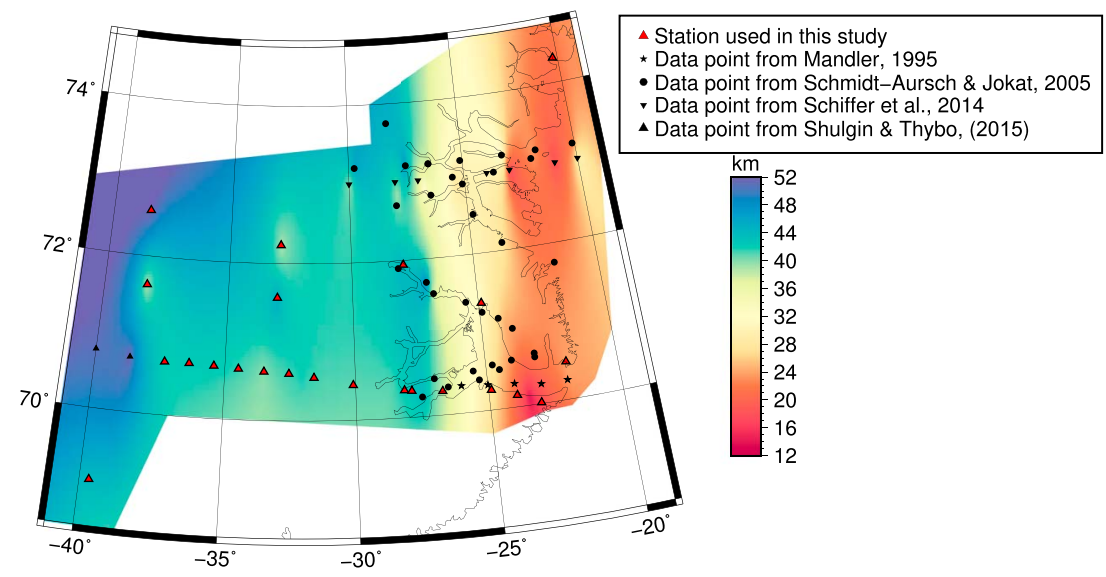

Figure 9. Interpolated Moho depth map based on all available data from the region, including the new RFs described here and data from Mandler (1995), Schmidt-Aursch and Jokat (2005), Schiffer et al. (2014), and Shulgin and Thybo (2015).

crust, this thinning must have been extreme. However, it cannot be excluded that underplating in relation to the large igneous activity mainly has taken place within the central parts of the volcanic province and thus may have left the rims of the volcanic province unaffected in the deep crust.

One may also speculate if we could have misinterpreted extremely high crustal velocity values at the base of the crust as mantle velocities, but a seismic refraction profile in Scoresbysund Fjord shows no sign of such a layer and identifies clear mantle velocity of $8.0 \mathrm{~km} / \mathrm{s}$ below a depth of $20 \mathrm{~km}$ for stations deployed along our profile and air gun shots in the fjord just outside the coast (Mandler, 1995). This profile does not cross the Jameson Basin, which is located 20-40 km further to the north, and the Caledonian affected areas are located even further to the north. Schmidt-Aursch and Jokat (2005) report a Moho at a depth of $22 \mathrm{~km}$ above clear mantle velocities of $8.0 \mathrm{~km} / \mathrm{s}$ below the Jameson Basin.

The observed general trend of westward crustal thickening toward central Greenland is in accordance with observations from seismic refraction by Schmidt-Aursch and Jokat (2005) in the eastern part at Scoresbysund Fjord, and Shulgin and Thybo (2015) in the western part on the ice sheet. The steep deepening at around $27^{\circ} \mathrm{W}$ coincides with the location where Schmidt-Aursch and Jokat (2005) also interpret abrupt Moho deepening, although their observations could not constrain the actual depth on the deep western side due to the limited extent of their profile toward the ice sheet.

Previous calculations of RF for station SUMG by Dahl-Jensen et al. (2003) and Kumar et al. (2007) led to very different estimates of Moho depth. Our analysis suggests a Moho depth of $51 \mathrm{~km}$, based on the combined velocity inversion of PRF and SRF. This supports the PRF results of a Moho depth of $49 \mathrm{~km}$ (Dahl-Jensen et al., 2003) rather than the value of $39 \mathrm{~km}$ obtained by a combination of PRF and SRF by Kumar et al. (2007). It appears that the latter depth may correspond to the top of the lower crust (Figure 6a) as suggested by Artemieva and Thybo (2008). The deep Moho may also find support from the results along the refraction seismic profile located $200 \mathrm{~km}$ further south, which indicate a total crustal thickness of $48 \mathrm{~km}$ below central Greenland and the presence of an approximately 20-km-thick lower crustal layer with very high $V_{p}$ (Shulgin \& Thybo, 2015).

Our inversion results generally show the presence of a low-velocity layer in the uppermost part of the crust on the coastal stations. The $V_{p} / V_{s}$ ratio in this low-velocity zone is very large $\left(V_{s}<3 \mathrm{~km} / \mathrm{s}, V_{p} / V_{s}>2\right.$ on STA02 + STA03, STA04, STA06) in the southern part of the region, which may indicate a high mafic content of the crust. This supports that there has been substantial addition of melts to the crust in connection with the formation of the volcanic province, and the low-velocity zone may identify the thickness of the volcanic sequences which then would show a westward thinning from approximately $7 \mathrm{~km}$ at the coast to its disappearance at STA09. The observed low $V_{s}$ and high $V_{p} / V_{s}$ may further indicate the presence of water-filled cracks. Liquid tends to reduce $V_{s}$ significantly, and leave $V_{p}$ relatively unaffected. Planke and Cambray (1998) find a similar high $V_{p} / V_{s}$ for the basalts at the offshore ODP hole 917A at a location slightly further to the south. 


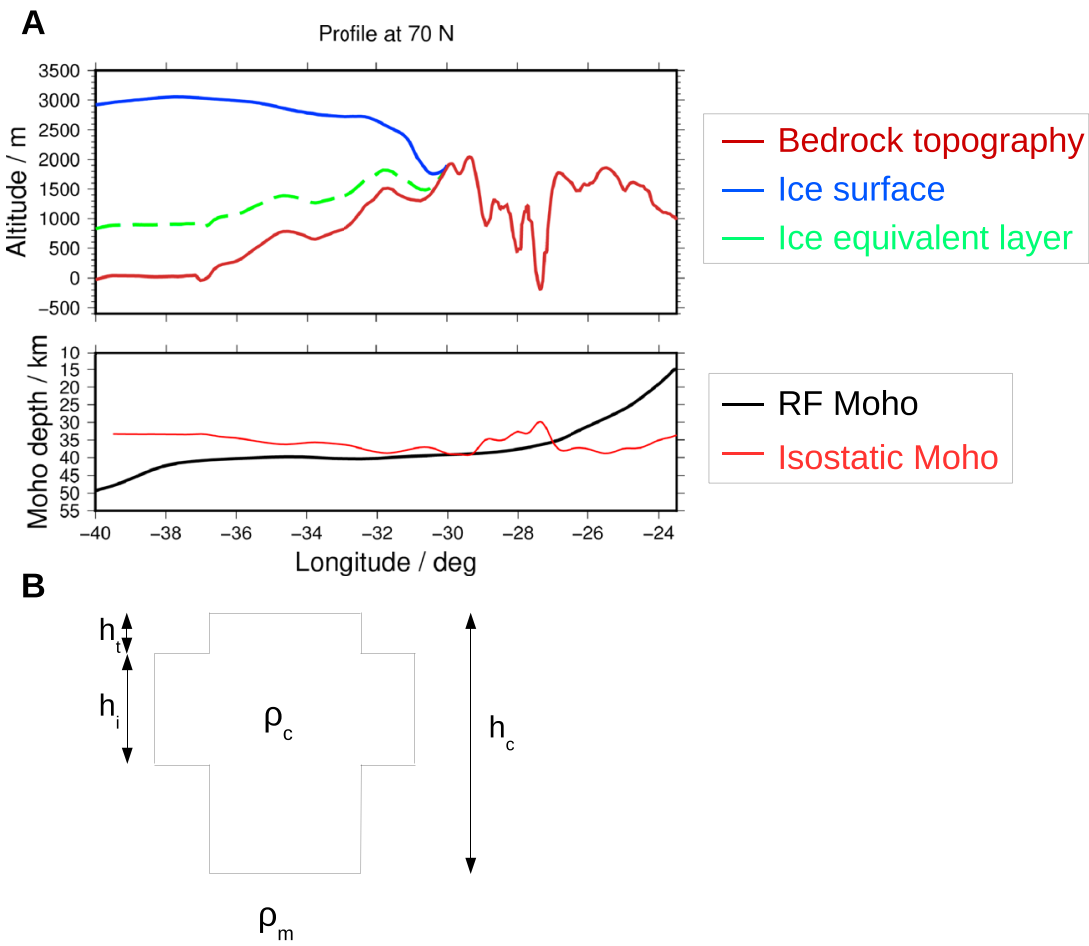

Figure 10. Profile along $70^{\circ} \mathrm{N}$. (a, top) Bedrock topography (brown), ice surface (blue), and a theoretical bedrock layer equivalent to the ice load (green dashed) using $0.8 \mathrm{~g} / \mathrm{cm}^{3}$ for the ice density and $2.75 \mathrm{~g} / \mathrm{cm}^{3}$ for bedrock. (bottom) Moho based on RF inversion results (black) and predicted Moho based on Airy-isostatic balance models for a constant density of $2.75 \mathrm{~g} / \mathrm{cm}^{3}$ (red). (b) Heights used for isostatic calculations.

The low-velocity layer to the north of Scoresbysund Fjord at STA24, SCO, and DBG, on the contrary, has low $V_{p} / V_{s}$, which indicates a different origin with a much lower mafic content than in the southern part of the study area. These stations were installed on Precambrian bedrock in the immediate vicinity of major sedimentary basins, and we suggest that the presence of sedimentary and metasedimentary strata causes the low-velocity layer with the observed $V_{p} / V_{S}$ ratio of around 1.70 which is normal for the upper crust.

Around stations STA11 + STA12, STA13, STA14 + 15, and STA19 in the center of the array we observe a relatively low $V_{s}$ and high $V_{p} / V_{s}$ ratio in the lower crust. According to results along the coincident refraction seismic profile, $V_{p}$ is normal for this part of the area, although it is significantly higher further to the west. This unusual $V_{p} / V_{s}$ could indicate the presence of fluids in the lower crust (Kennedy \& van Soest, 2007; Vinnik et al., 2017).

\subsection{Isostasy}

The presence of the ice sheet complicates assessment of the isostatic state of the region because the density of ice (approximately $0.8 \mathrm{~g} / \mathrm{cm}^{3}$ ) is much smaller than the bedrock (approximately $2.75 \mathrm{~g} / \mathrm{cm}^{3}$ ). Moho deepens significantly along the profile at $70^{\circ} \mathrm{N}$ from around $15 \mathrm{~km}$ at the coast to around $50 \mathrm{~km}$ close to the center of Greenland (Figure 10b). The topography increases from around 1,000 $\mathrm{m}$ near the coast to around 3,000 $\mathrm{m}$ in the center of Greenland with a pronounced low at around $27-29^{\circ} \mathrm{W}$, where the profile line crosses one of the many fjords in the area. The overall topographic variation could at first sight be indicative of Airy-type crustal isostatic equilibrium.

However, the presence of the low-density ice sheet should be taken into consideration. The bedrock topography is relatively high in the eastern end of the profile and decreases gradually from around $2,000 \mathrm{~m}$ at $30^{\circ} \mathrm{W}$ to around sea level $(0 \mathrm{~m})$ in the central part of Greenland at $40^{\circ} \mathrm{W}$. We have transformed the ice layer into an equivalent layer of bedrock which results in the "equivalent topography" illustrated by the dashed, green curve in Figure 10a, using $0.8 \mathrm{~g} / \mathrm{cm}^{3}$ for the ice density and $2.75 \mathrm{~g} / \mathrm{cm}^{3}$ for bedrock. This bedrock density corresponds to an average crustal $V_{p}$ of $6.23 \mathrm{~km} / \mathrm{s}$ according to the Nafe-Drake relationship. 
To assess whether the topography is isostatically supported by the crust, we calculate predicted isostatic Moho depths based on the assumption of full support by Airy isostasy (Figure 10b). Under this assumption the relation between total crustal thickness $\left(h_{c}\right)$ and topography $\left(h_{t}\right)$ can be expressed by

$$
h_{c}=h_{i}+h_{t}(1+\rho c /(\rho m-\rho c))
$$

where $h_{i}$ is the crustal thickness where the surface is at sea level (here we use $28 \mathrm{~km}$ corresponding to the Moho depth at station SCO), $\rho_{c}$ is the average density of the crust, and $\rho_{m}$ is the average density of the mantle $\left(3.3 \mathrm{~g} / \mathrm{cm}^{3}\right.$; Figure 10c). Hereby we assume that there are no lateral density changes in the crust and upper mantle along the profile $\left(\rho_{c}=2.75 \mathrm{~g} / \mathrm{cm}^{3}\right.$; red line), which is justified by the very modest lateral variation in crustal $V_{s}$ along the profile (Figure 7). The calculated isostatic Moho profile shows relatively modest variation. It shows clear differences to the Moho profile derived by RF inversion, in particular at the eastern and western parts of the profile. In the east the observed Moho is almost $20 \mathrm{~km}$ shallower than predicted for Airy isostasy, while for the western part the observed Moho is substantially deeper than predicted.

We conclude that the relation between the equivalent topography and crustal thickness cannot be explained by Airy-type isostasy for the crust alone. We also notice the positive free air gravity anomaly in the eastern end of the profile with an amplitude of at least $+80 \mathrm{mGal}$ (Artemieva et al., 2016). Future studies, based on refraction seismic profiling (Shulgin \& Thybo, 2015), will investigate if crustal density variation along the profile may explain the low bedrock topography in central Greenland.

In any case, the observed true topographic variation in relation to the gradual Moho shallowing outside the ice sheet cannot be explained by simple Airy-type crustal isostasy. There is no indication for significant variation in crustal velocity and therefore also not for variation in crustal density in the eastern part of the profile. This indicates that crustal isostasy cannot explain the significant topographic variation in the study area. Similar results have been found on the opposite side of the Atlantic Ocean in southern Norway, where it appears that only two thirds of the topographic relief may be explained by Airy-type isostasy for the topography around the Norwegian mountains (Anell et al., 2010; Stratford et al., 2009) such that Pratt type of isostasy may be inferred to explain the transition into the Baltic Shield (Frassetto \& Thybo, 2013).

\section{Conclusions}

We have presented a model of the crustal velocity structure in central-eastern Greenland between the Atlantic coast and Summit Station based on joint inversion of $P$ and $S$ receiver functions. Our results show a westward deepening of Moho from less than $20 \mathrm{~km}$ at the coast to up to $50 \mathrm{~km}$ in central Greenland. At the south-eastern edge of our study area we observe an extremely thin crust close to the coast in the area of substantial volcanic sequences.

The coastal stations show the presence of a low-velocity layer in the uppermost crust. In the southern part of the study area, very high $(>2) V_{p} / V_{s}$ ratio indicates high mafic content, originating from addition of magmatic material to the crust to 7-km depth. The extremely high $V_{p} / V_{s}(>2)$ is mainly due to low $V_{s}$, whereas $V_{p}$ is relatively constant. This indicates that water-filled cracks may be present in the basaltic material. The northern coastal stations also show a low-velocity layer in the same depth range, but with normal $V_{p} / V_{s}$. This observation may be explained by the presence of sedimentary basins in the vicinity of the stations, which, however, were installed on Precambrian bedrock.

In the center of our study area the lower crust has low $V_{s}$ and high $V_{p} / V_{s}$ lower crust, which may be attributed to the presence of fluids in the lower crust. The westernmost part of the study area includes a lower crust with high $V_{s}$ and high $V_{p} / V_{s}$ ratio coinciding with very deep Moho which might be indicative of a high mafic content of the lower crust, for example, from magmatic underplating.

The observed crustal thicknesses cannot be explained by Airy-type isostasy. The assessment of isostasy is complicated by the presence of the ice sheet and further analysis of the density structure is required for assessment of the state of isostasy in the area, which includes the highest mountains in Greenland.

\section{References}

Amante, C. \& Eakins, B. (2012). ETOPO1, Global 1 Arc-Minute Ocean Depth and Land Elevation from the US National Geophysical Dato Center (NGDC). https://doi.org/10.1594/PANGAEA.769615 
Amante, C., \& Eakins, B. W. (2009). ETOPO1 1 arc-minute global relief model: Procedures, data sources and analysis (NOAA Technical Memorandum NESDIS NGDC-24). Boulder, CO: National Geophysical Data Center, NOAA. https://doi.org/10.7289/V5C8276M Anell, I., Thybo, H., \& Artemieva, I. (2009). Cenozoic uplift and subsidence in the North Atlantic region: Geological evidence revisited. Tectonophysics, 474(1-2), 78-105. https://doi.org/10.1016/j.tecto.2009.04.006

Anell, I., Thybo, H., \& Rasmussen, E. (2012). A synthesis of Cenozoic sedimentation in the North Sea. Basin Research, 24(2), 154-179. https://doi.org/10.1111/j.1365-2117.2011.00517.x

Anell, I., Thybo, H., \& Stratford, W. (2010). Relating Cenozoic North Sea sediments to topography in southern Norway: The interplay between tectonics and climate. Earth and Planetary Science Letters, 300(1-2), 19-32. https://doi.org/10.1016/j.epsl.2010.09.009

Artemieva, I. M., \& Thybo, H. (2008). Deep Norden: Highlights of the lithospheric structure of northern Europe, Iceland, and Greenland. In Episodes (Vol. 31, pp. 98-106).

Artemieva, I. M., \& Thybo, H. (2013). EUNAseis: A seismic model for Moho and crustal structure in Europe, Greenland, and the North Atlantic region. Tectonophysics, 609, 97-153. https://doi.org/10.1016/j.tecto.2013.08.004

Artemieva, I. M., Thybo, H., \& Shulgin, A. (2016). Geophysical constraints on geodynamic processes at convergent margins: A global perspective. Gondwana Research, 33, 4-23. https://doi.org/10.1016/j.gr.2015.06.010

Berkhout, A. J. (1977). Least square inverse filtering and wavelet deconvolution. Geophysics, 42(7), 1369-1383. https://doi.org/10.1190/ 1.1440798

Bevis, M., Wahr, J., Khan, S. A., Madsen, F. B., Brown, A., Willis, M., et al. (2012). Bedrock displacements in Greenland manifest ice mass variations, climate cycles and climate change. Proceedings of the National Academy of Sciences of the United States of America, 109(30), 11,944-11,948. https://doi.org/10.1073/pnas.1204664109

Biswas, N. N. (1972). Eart-flattening procedure for propagation of Rayleigh wave. Pure and Applied Geophysics, 96(1), 61-74. https://doi. org/10.1007/BF00875629

Brooks, C. K. (2011). The East Greenland rifted volcanic margin. In Geological Survey of Denmark and Greenland Bulletin (Vol. 24 pp. 1-96). Copenhagen, Denmark: Geological Survey of Denmark and Greenland (GEUS). Retrieved from http://eng.geus.dk/productsservices-facilities/publications/geus-bulletin/bulletin-24/

Chian, D., \& Louden, K. (1992). The structure of Archean-Ketilidian crust along the continental shelf of southwestern Greenland from a seismic refraction profile. Canadian Journal of Earth Sciences, 29(2), 301-313. https://doi.org/10.1139/e92-027

Clinton, J. F., Nettles, M., Walter, F., Anderson, K., Dahl-Jensen, T., Giardini, D., et al. (2014). Real-time geophysical data enhance Earth system monitoring in Greenland. Eos, Transactions American Geophysical Union, 95(2), 13-2014. https://doi.org/10.1002/ 2014EO020001

Dahl-Jensen, T., Larsen, T. B., Woelbern, I., Bach, T., Hanka, W., Kind, R., et al. (2003). Depth to Moho in Greenland: Receiver-function analysis suggests two Proterozoic blocks in Greenland. Earth and Planetary Science Letters, 205(3-4), 379-393. https://doi.org/10.1016/ S0012-821X(02)01080-4

Dahl-Jensen, T., Thybo, H., Hopper, J., \& Rosing, M. (1998). Crustal structure at the SE Greenland margin from wide-angle and normal incidence seismic data. Tectonophysics, 288(1-4), 191-198. https://doi.org/10.1016/S0040-1951(97)00292-8

Darbyshire, F. A., Dahl-Jensen, T., Larsen, T. B., Voss, P. H., \& Joyal, G. (2018). Crust and uppermost-mantle structure of Greenland and the Northwest Atlantic from Rayleigh wave group velocity tomography. Geophysical Journal International, 212, 1546-1569. https://doi. org/10.1093/gii/ggx479

Darbyshire, F. A., Larsen, T. B., Mosegaard, K., Dahl-Jensen, T., Gudmundsson, O., Bach, T., et al. (2004). A first detailed look at the Greenland lithosphere and upper mantle, using Rayleigh wave tomography. Geophysical Journal International, 158, 267-186.

Doré, A. G., Cartwright, J. A., Stoker, M. S., Turner, J. P., \& White, N. (Eds.) (2002). Exhumation of the North Atlantic Margin. Geological Society of London.

Døssing, A., Japsen, P., Watts, A. B., Nielsen, T., Jokat, W., Thybo, H., \& Dahl-Jensen, T. (2016). Miocene uplift of the NE Greenland margin linked to plate tectonics: seismic evidence from the Greenland Fracture Zone, NE Atlantic. Tectonics, 35, 257-282. https://doi.org/ $10.1002 / 2015$ TC004079

England, R. W., \& Ebbing, J. (2012). Crustal structure of central Norway and Sweden from integrated modelling of teleseismic receiver functions and the gravity anomaly. Geophysical Journal International, 191(1), 1-11. https://doi.org/10.1111/j.1365246X.2012.05607.x

Farra, V., \& Vinnik, L. (2000). Upper mantle stratification by $P$ and $S$ receiver functions. Geophysical Journal International, 141(3), 699-712. https://doi.org/10.1046/j.1365-246x.2000.00118.x

Frassetto, A., \& Thybo, H. (2013). Receiver function analysis of the crust and upper mantle in Fennoscandia-Isostatic implications. Earth and Planetary Science Letters, 381, 234-246.

Funck, T., Erlendsson, Ö., Geissler, W. H., Gradmann, S., Kimbell, G. S., McDermott, K., \& Petersen, U. K. (2017). A review of the NE Atlantic conjugate margins based on seismic refraction data. Geological Society, London, Special Publications, 447(1), 171-205.

Gabrielsen, R.H., Faleide, J.I., Pascal, C., Braathen, A., Nystuen, J.P., Etzelmuller, B., O'Donnell, S. (2010). Latest Caledonian to Present tectonomorphological development of southern Norway. Marine and Petroleum Geology 27, 709-723.

Haskell, N. A. (1962). Crustal reflection of plane $P$ and SV waves. Journal of Geophysical Research, 67(12), 4751-4768.

Hendriks, B.W.H., Redfield, T.F. (2005). Apatite fission track and (U-Th)/He data from Fennoscandia: An example of underestimation of fission track annealing in apatite. Earth and Planetary Science Letters 236, 443-45.

Henriksen, N., Higgins, A., Kalsbeek, F., \& Pulvertaft, T. C. R. (2009). Greenland from Archaean to Quaternary: Descriptive text to the 1995 Geological map of Greenland, 1: 2,500,000.

Hermann, T., \& Jokat, W. (2016). Crustal structure off Kong Oscar Fjord, east Greenland: Evidence for focused melt supply along the Jan Mayen Fracture Zone. Tectonophysics, 691, 110-119.

Holbrook, W. S., Larsen, H., Korenaga, J., Dahl-Jensen, T., Reid, I. D., Kelemen, P., et al. (2001). Mantle thermal structure and active upwelling during continental breakup in the North Atlantic. Earth and Planetary Science Letters, 190(3), 251-266.

Hopper, J. R., Dahl-Jensen, T., Holbrook, W. S., Larsen, H. C., Lizarralde, D., Korenaga, J., et al. (2003). Structure of the SE Greenland margin from seismic reflection and refraction data: Implications for nascent spreading center subsidence and asymmetric crustal accretion during North Atlantic opening. Journal of Geophysical Research, 108(B5), 2269. https://doi.org/10.1029/2002JB001996

Japsen, P., Bonow, J. M., Green, P. F., Chalmers, J. A., \& Lidmar-Bergström, K. (2006). Elevated, passive continental margins: Long-term highs or Neogene uplifts? New evidence from West Greenland. Earth and Planetary Science Letters, 248, 330-339.

Japsen, P., Bonow, J.M., Green, P.F., Chalmers, J.A., Lidmar-Bergström, K. (2009). Formation, uplift and dissection of planation surfaces at passive continental margins-A new approach. Earth Surface Processes and Landforms 34, 683-699.

Japsen, P., \& Chalmers, J. A. (2000). Neogene uplift and tectonics around the North Atlantic: overview. Global and Planetary Change, 24, 165-173. 
Japsen, P., Green, P. F., Bonow, J. M., Nielsen, T. F., \& Chalmers, J. A. (2014). From volcanic plains to glaciated peaks: Burial, uplift and exhumation history of southern East Greenland after opening of the NE Atlantic. Global and Planetary Change, 116, 91-114.

Japsen, P., Green, P. F., \& Chalmers, J. A. (2005). Separation of Palaeogene and Neogene uplift on Nuussuaq, West Greenland. Journal of the Geological Society, 162, 299-314.

Jolley, D. W., \& Bell, B. R. (2002). The evolution of the North Atlantic Igneous Province and the opening of the NE Atlantic rift. Geological Society, London, Special Publications, 197(1), 1-13.

Kennedy, B. M., \& van Soest, M. C. (2007). Flow of mantle fluids through the ductile lower crust: Helium isotope trends. Science, 318, 1433-1436.

Kennett, B. L. N., \& Engdahl, E. R. (1991). Traveltimes for global earthquake location and phase identification. Geophysical Journal International, 105(2), 429-465.

Kiselev, S., Vinnik, L., Oreshin, S., Gupta, S., Rai, S., Singh, A., et al. (2008). Lithosphere of the Dharwar craton by joint inversion of $P$ and $S$ receiver functions. Geophysical Journal International, 173(3), 1106-1118.

Kraft, H. A., Vinnik, L., \& Thybo, H. (2018). Mantle transition zone beneath central-eastern Greenland: Possible evidence for a deep tectosphere from receiver functions. Tectonophysics, 728-729, 34-40. https://doi.org/10.1016/j.tecto.2018.02.008

Kumar, P., Kind, R., Priestley, K., \& Dahl-Jensen, T. (2007). Crustal structure of Iceland and Greenland from receiver function studies. Journal of Geophysical Research, 112, B03301. https://doi.org/10.1029/2005JB003991

Kvarven, T., Mjelde, R., Hjelstuen, B. O., Faleide, J. I., Thybo, H., Flueh, E. R., \& Murai, Y. (2016). Crustal composition of the More Margin and compilation of a conjugate Atlantic margin transect. Tectonophysics, 666, 144-157. https://doi.org/10.1016/j.tecto.2015.11.002

Larsen, L. M., Pedersen, A. K., Tegner, C., \& Duncan, R. A. (2014). Eocene to Miocene igneous activity in NE Greenland: northward younging of magmatism along the East Greenland margin. Journal of the Geological Society, 171(4), 539-553.

Lawver, L. A., \& Müller, R. D. (1994). Iceland hotspot track. Geology, 22(4), 311-314.

Mandler, H. (1995). Die Struktur der Erdkruste im Bereich des Scoresby Sund, Ostgrön- land: Ergebnisse refraktionsseismischer und graivmetrischer Untersuchungen, (PhD thesis). Universität Bremen.

Maupin, V., Agostini, A., Artemieva, I., Balling, N., Beekman, F., Ebbing, J., et al. (2013). The deep structure of the Scandes and its relation to tectonic history and present-day topography. Tectonophysics 602, 15-37.

Mosegaard, K. \& Vestergaard, P. D. (1991). A simulated annealing approach to seismic model optimization with sparse prior information. Geophysical Prospecting, 39(5), 599-611.

Pedersen, V. K., Nielsen, S. B., \& Gallagher, K. (2012). The post-orogenic evolution of the Northeast Greenland Caledonides constrained from apatite fission track analysis and inverse geodynamic modeling. Tectonophysics, 530, 318-330.

Petrov, O., Morozov, A., Shokalsky, S., Kashubin, S., Artemieva, I. M., Sobolev, N., et al. (2016). Crustal structure and tectonic model of the Arctic region. Earth-Science Reviews, 154, 29-71. https://doi.org/10.1016/j.earscirev.2015.11.013

Planke, S., \& Cambray, H. (1998). 38. Seismic properties of flood basalts from hole 917A downhole data, Southeast Greenland volcanic margin. In Proceedings of the Ocean Drilling Program (Vol. 152, pp. 453-462).

Reid, I., \& Jackson, H. (1981). Oceanic spreading rate and crustal thickness. Marine Geophysical Researches, 5(2), 165-172.

Schiffer, C., Balling, N., Jacobsen, B. H., Stephenson, R. A., \& Nielsen, S. B. (2014). Seismological evidence for a fossil subduction zone in the East Greenland Caledonides. Geology, 42(4), 311-314.

Schlindwein, V. \& Jokat, W. (1999). Structure and evolution of the continental crust of northern east Greenland from integrated geophysical studies. Journal of Geophysical Research, 104(B7), 15,227-15,245.

Schmidt-Aursch, M. C., \& Jokat, W. (2005). The crustal structure of central East Greenland-I: From the Caledonian orogen to the Tertiary igneous province. Geophysical Journal International, 160(2), 736-752.

Shulgin, A., \& Thybo, H. (2015). Seismic explosion sources on an ice cap-Technical considerations. Polar Science, 9(1), 107-118.

Silveira, G., Vinnik, L., Stutzmann, E., Farra, V., Kiselev, S., Morais, I., 2010. Stratification of the Earth beneath the Azores from $P$ and $S$ receiver functions. Earth and Planetary Science Letters 299, 91-103.

Stratford, W., \& Thybo, H. (2011). Seismic structure and composition of the crust beneath the southern Scandes, Norway. Tectonophysics, 502, 364-382.

Stratford, W., Thybo, H., Faleide, J. I., Olesen, O., \& Tryggvason, A. (2009). New Moho map for onshore southern Norway. Geophysical Journal International, 178(3), 1755-1765.

Thybo, H., \& Artemieva, I. M. (2013). Moho and magmatic underplating in continental lithosphere. Tectonophysics, 609, 605-619.

Torsvik, T. H., Amundsen, H. E., Trønnes, R. G., Doubrovine, P. V., Gaina, C., Kusznir, N. J., et al. (2015). Continental crust beneath southeast Iceland. Proceedings of the National Academy of Sciences of the United States of America, 112(15), E1818-E1827.

Ucisik, N., Gudmundsson, Ó., Hanka, W., Dahl-Jensen, T., Mosegaard, K., \& Priestley, K. (2008). Variations of shear-wave splitting in Greenland: Mantle anisotropy and possible impact of the Iceland plume. Tectonophysics, 462(1), 137-148.

Vinnik, L. (1977). Detection of waves converted from $P$ to SV in the mantle. Physics of the Earth and Planetary Interiors, 15(1):39-45.

Vinnik, L., Aleshin, I., Kaban, M., Kiselev, S., Kosarev, G., Oreshin, S., \& Reigber, C. (2006). Crust and mantle of the Tien Shan from data of the receiver function tomography. Izvestiya Physics of the Solid Earth, 42(8), 639-651.

Vinnik, L., Oreshin, S., Makeyeva, L., \& Dündar, S. (2017). Fluid-filled porosity of magmatic underplates from joint inversion of $P$ and $S$ receiver functions. Geophysical Journal International, 209, 961-968. https://doi.org/10.1093/gji/ggx067

Vinnik, L.P., Chevrot, S., Montagner, J.-P., Guyot, F. (1999). Teleseismic traveltime residuals in North America and anelasticity of the asthenosphere. Physics of the Earth and Planetary Interiors 116, 92-103.

Voss, M., \& Jokat, W. (2007). Continent-ocean transition and voluminous magmatic underplating derived from $P$-wave velocity modeling of the East Greenland continental margin. Geophysical Journal International, 170(2), 580-604.

Voss, M., Schmidt-Aursch, M. C., \& Jokat, W. (2009). Variations in magmatic processes along the East Greenland volcanic margin. Geophysical Journal International, 177. https://doi.org/10.1111/j.1365-246X.2009.04077.x

Weidle, C., Maupin, V., Ritter, J., Kvaerna, T., Schweitzer, J., Balling, N., et al. (2010). MAGNUS—A seismological broadband experiment to resolve crustal and upper mantle structure beneath the Southern Scandes Mountains in Norway. Seismological Research Letters 81, $76-84$.

White, R. S., McKenzie, D., \& O'Nions, R. K. (1992). Oceanic crustal thickness from seismic measurements and rare Earth element inversions. Journal of Geophysical Research, 97(B13), 19,683-19,715.

Wittlinger, G., \& Farra, V. (2012). Observation of low shear wave velocity at the base of the polar ice sheets: Evidence for enhanced anisotropy. Geophysical Journal International, 190, 391-405. https://doi.org/10.1111/j.1365-246X.2012.05474.x 